\title{
Global tropospheric hydroxyl distribution, budget and reactivity
}

\author{
Jos Lelieveld, Sergey Gromov, Andrea Pozzer, and Domenico Taraborrelli \\ Max Planck Institute for Chemistry, Atmospheric Chemistry Department, P.O. Box 3060, 55020 Mainz, Germany \\ Correspondence to: Jos Lelieveld (jos.lelieveld@mpic.de)
}

Received: 29 February 2016 - Published in Atmos. Chem. Phys. Discuss.: 11 March 2016

Revised: 27 August 2016 - Accepted: 18 September 2016 - Published: 5 October 2016

\begin{abstract}
The self-cleaning or oxidation capacity of the atmosphere is principally controlled by hydroxyl $(\mathrm{OH})$ radicals in the troposphere. Hydroxyl has primary $(P)$ and secondary $(S)$ sources, the former mainly through the photodissociation of ozone, the latter through $\mathrm{OH}$ recycling in radical reaction chains. We used the recent Mainz Organics Mechanism (MOM) to advance volatile organic carbon (VOC) chemistry in the general circulation model EMAC (ECHAM/MESSy Atmospheric Chemistry) and show that $S$ is larger than previously assumed. By including emissions of a large number of primary $\mathrm{VOC}$, and accounting for their complete breakdown and intermediate products, MOM is mass-conserving and calculates substantially higher $\mathrm{OH}$ reactivity from VOC oxidation compared to predecessor models. Whereas previously $P$ and $S$ were found to be of similar magnitude, the present work indicates that $S$ may be twice as large, mostly due to $\mathrm{OH}$ recycling in the free troposphere. Further, we find that nighttime $\mathrm{OH}$ formation may be significant in the polluted subtropical boundary layer in summer. With a mean $\mathrm{OH}$ recycling probability of about $67 \%$, global $\mathrm{OH}$ is buffered and not sensitive to perturbations by natural or anthropogenic emission changes. Complementary primary and secondary $\mathrm{OH}$ formation mechanisms in pristine and polluted environments in the continental and marine troposphere, connected through long-range transport of $\mathrm{O}_{3}$, can maintain stable global $\mathrm{OH}$ levels.
\end{abstract}

\section{Introduction}

The removal of most natural and anthropogenic gases from the atmosphere - important for air quality, the ozone layer and climate - takes place through their oxidation by hydroxyl $(\mathrm{OH})$ radicals in the troposphere. The central role of tropospheric $\mathrm{OH}$ in the atmospheric oxidation capacity (or effi- ciency) has been recognized since the early 1970s (Levy II, 1971; Crutzen, 1973; Logan et al., 1981, Ehhalt et al., 1991). The primary $\mathrm{OH}$ formation rate $(P)$ depends on the photodissociation of ozone $\left(\mathrm{O}_{3}\right)$ by ultraviolet (UV) sunlight - with a wavelength of the photon $(h v)$ shorter than $330 \mathrm{~nm}-$ in the presence of water vapor:

$\mathrm{O}_{3}+h v(\lambda<330 \mathrm{~nm}) \rightarrow \mathrm{O}\left({ }^{1} \mathrm{D}\right)+\mathrm{O}_{2}$,

$\mathrm{O}\left({ }^{1} \mathrm{D}\right)+\mathrm{H}_{2} \mathrm{O} \rightarrow 2 \mathrm{OH}$.

(Note that the formal notation of hydroxyl is $\mathrm{HO}$, indicating one unpaired electron on the oxygen atom. For brevity we omit the dot and use the notation $\mathrm{OH}$, and similarly for other radicals.) Since the stratospheric ozone layer in the tropics is relatively thin, UV radiation is less strongly attenuated compared to the extratropics; additionally, because the solar zenith angle and water vapor concentrations are relatively high, zonal $\mathrm{OH}$ is highest at low latitudes in the lower to middle troposphere (Crutzen and Zimmermann, 1991; Spivakovsky et al., 2000).

The $\mathrm{OH}$ radicals attack reduced and partly oxidized gases such as methane $\left(\mathrm{CH}_{4}\right)$, non-methane volatile organic compounds (VOCs) and carbon monoxide (CO), so that these gases only occur in trace amounts, e.g.,

$\mathrm{CO}+\mathrm{OH} \rightarrow \mathrm{CO}_{2}+\mathrm{H}$,

$\mathrm{H}+\mathrm{O}_{2}(+M) \rightarrow \mathrm{HO}_{2}(+M)$,

where $M$ is an air molecule that removes excess energy from reaction intermediates by collisional dissipation. Because $\mathrm{OH}$ is highly reactive, it has an average tropospheric lifetime of about 1-2 s. After the initial $\mathrm{OH}$ reaction (Reaction R3) peroxy radicals are produced (Reaction R4), which can combine to form peroxides:

$\mathrm{HO}_{2}+\mathrm{HO}_{2} \rightarrow \mathrm{H}_{2} \mathrm{O}_{2}+\mathrm{O}_{2}$, 


$$
\begin{aligned}
& \mathrm{RO}_{2}+\mathrm{HO}_{2} \rightarrow \mathrm{ROOH}+\mathrm{O}_{2}, \\
& \rightarrow \mathrm{RO}+\mathrm{O}_{2}+\mathrm{OH}, \\
& \rightarrow \mathrm{ROH}+\mathrm{O}_{3} .
\end{aligned}
$$

$\mathrm{RH}$ is a VOC from which $\mathrm{OH}$ can abstract the hydrogen to form water and an alkyl radical, which reacts with $\mathrm{O}_{2}$ to form a peroxy radical, $\mathrm{RO}_{2}$. After peroxide formation (Reactions R5, R6a) the reaction chains can either propagate or terminate, the latter by deposition. Propagation of the chain leads to higher-generation reaction products and secondary $\mathrm{OH}$ formation $(S)$, which can be understood as $\mathrm{OH}$ recycling. For example, the photolysis of $\mathrm{ROOH}$ leads to $\mathrm{OH}$ production. In air that is directly influenced by pollution emissions $S$ is largely controlled by nitrogen oxides $\left(\mathrm{NO}+\mathrm{NO}_{2}=\mathrm{NO}_{x}\right)$ :

$\mathrm{NO}+\mathrm{HO}_{2} \rightarrow \mathrm{NO}_{2}+\mathrm{OH}$.

This reaction, referred to as the $\mathrm{NO}_{x}$ recycling mechanism of $\mathrm{OH}$, also leads to ozone production through photodissociation of $\mathrm{NO}_{2}$ by ultraviolet and visible light:

$\mathrm{NO}_{2}+h v(\lambda<430 \mathrm{~nm}) \rightarrow \mathrm{NO}+\mathrm{O}\left({ }^{3} \mathrm{P}\right)$,

$\mathrm{O}\left({ }^{3} \mathrm{P}\right)+\mathrm{O}_{2}(+M) \rightarrow \mathrm{O}_{3}(+M)$.

However, in strongly polluted air $\mathrm{NO}_{2}$ can locally be a large $\mathrm{OH}$ sink, and in such environments the net effect of $\mathrm{NO}_{x}$ on $\mathrm{OH}$ is self-limiting through the reaction

$\mathrm{NO}_{2}+\mathrm{OH}(+M) \rightarrow \mathrm{HNO}_{3}(+M)$.

Conversely, under low- $\mathrm{NO}_{x}$ conditions, mostly in pristine air, secondary $\mathrm{OH}$ formation by other mechanisms is important:

$\mathrm{O}_{3}+\mathrm{HO}_{2} \rightarrow 2 \mathrm{O}_{2}+\mathrm{OH}$,

$\mathrm{H}_{2} \mathrm{O}_{2}+h v(\lambda<550 \mathrm{~nm}) \rightarrow \mathrm{OH}+\mathrm{OH}$.

These reactions are referred to as the $\mathrm{O}_{x}$ recycling mechanism of $\mathrm{OH}$. In prior work we suggested that the strong growth of air pollution since industrialization, especially in the 20th century, has drastically changed $\mathrm{OH}$ production and loss rates but that globally the balance between $P$ and $S$ changed little (Lelieveld et al., 2002). This is associated with a relatively constant $\mathrm{OH}$ recycling probability $r$, defined as $r=1-P / G$, in which $G$ is gross $\mathrm{OH}$ formation $(G=P+S)$; $P, S$ and $G$ have unit moles $\mathrm{yr}^{-1}$. We computed that globally $r$ has changed little since preindustrial times, remaining at about $50 \%$. Thus, in the past century $G$ (the atmospheric oxidation power) kept pace with the growing $\mathrm{OH}$ sink related to the emissions of reduced and partly oxidized pollution gases. Lelieveld et al. (2002) performed perturbation simulations, applying pulse emissions of $\mathrm{NO}_{x}$ and $\mathrm{CH}_{4}$, to compute the impact on $\mathrm{OH}$. This showed that, at an $\mathrm{OH}$ recycling probability of $60 \%$ or higher, these perturbations have negligible influence on $\mathrm{OH}$ (their Fig. 6). Therefore, at $r>60 \%$ the atmospheric chemical system can be considered to be buffered.

While globally $r$ has remained approximately constant, the mean tropospheric $\mathrm{OH}$ concentration and the lifetime of $\mathrm{CH}_{4}$ $\left(\tau_{\mathrm{CH}_{4}}\right)$ have also changed comparatively little, for example within a spread of about $15 \%$ calculated by a 17 -member ensemble of atmospheric chemistry-transport models (Naik et al., 2013). Despite substantial differences in $\mathrm{OH}$ concentrations and $\tau_{\mathrm{CH}_{4}}$ among the models, simulations of emission scenarios according to several representative concentration pathways (RCPs) indicate that future $\mathrm{OH}$ changes will probably also be small, i.e., well within $10 \%$ (Voulgarakis et al., 2013). We interpret the relative constancy of $r$, mean $\mathrm{OH}$ and $\tau_{\mathrm{CH}_{4}}$ as an indication that global $\mathrm{OH}$ is buffered against perturbations. This is corroborated by studies based on observations of methyl chloroform, with known sources and $\mathrm{OH}$ reaction as the main sink, showing small interannual variability of global $\mathrm{OH}$ and small interhemispheric difference in OH (Krol and Lelieveld, 2003; Montzka et al., 2011; Patra et al., 2014).

For our previous estimates of $P$ and $S$ we used a chemistry-transport model with the Carbon Bond Mechanism (CBM) to represent non-hydrocarbon chemistry (Houweling et al., 1998). This mechanism aggregates organic compounds into categories of species according to molecular groups and has been successfully used to simulate ozone concentrations with air quality models (Stockwell et al., 2012). However, such chemical schemes are not massconserving, e.g., for carbon, and are optimized for conditions in which $\mathrm{NO}_{x}$ dominates $r$, while in low- $\mathrm{NO}_{x}$ environments other mechanisms may be important, for example through the chemistry of non-methane VOCs emitted by vegetation (Lelieveld et al., 2008), as reviewed by Vereecken and Francisco (2012), Stone et al. (2012) and Monks et al. (2015). A limitation of the CBM and other, similar mechanisms is that second- and higher-generation reaction products are lumped or ignored for computational efficiency, whereas they can contribute importantly to $\mathrm{OH}$ recycling and ozone chemistry (Butler et al., 2011; Taraborrelli et al., 2012).

Here we apply the Mainz Organics Mechanism (MOM), which accounts for recent developments in atmospheric VOC chemistry. MOM is a further development of the Mainz Isoprene Mechanism (Taraborrelli et al., 2009, 2012). In addition to isoprene, MOM computes the chemistry of saturated and unsaturated hydrocarbons, including terpenes and aromatics (Cabrera-Perez et al., 2016). We use it to estimate the role of radical production through reactions of oxidized VOC, referred to as the OVOC recycling mechanism of $\mathrm{OH}$, being contrasted with the $\mathrm{NO}_{x}$ and $\mathrm{O}_{x}$ recycling mechanisms of $\mathrm{OH}$. Based on this scheme, implemented in the ECHAM/MESSy Atmospheric Chemistry general circulation model (EMAC), we provide an update of global $\mathrm{OH}$ calculations, sources, sinks, tropospheric distributions, $\mathrm{OH}$ reactivity, and the lifetime of $\mathrm{CH}_{4}$ and $\mathrm{CO}$, and we discuss implications for atmospheric chemistry. We contrast the bound- 
ary layer and free troposphere (BL and FT), the Northern and Southern Hemisphere (NH and $\mathrm{SH}$ ) and the tropics and extratropics. We show that complementary $\mathrm{OH}$ recycling mechanisms in terrestrial, marine, pristine and polluted environments, interconnected through atmospheric transport, sustain stable levels of hydroxyl in the global troposphere.

\section{VOC chemistry and model description}

To reconcile observations of high $\mathrm{OH}$ concentrations over the Amazon rainforest with models that predicted low $\mathrm{OH}$ concentrations, we have proposed that the chemistry of isoprene recycle $\mathrm{OH}$, e.g., involving organic peroxy radicals (Lelieveld et al., 2008). Progress on such reactions was reported by Taraborrelli et al. (2012) and incorporated into a predecessor version of the present chemistry scheme. Laboratory experimental results by Groß et al. (2014a, b) provided additional evidence and insight into this type of chemistry, indicating that $\mathrm{OH}$ formation via Reaction (R6b) $\left(\mathrm{RO}_{2}+\mathrm{HO}_{2}\right)$ had previously been underestimated significantly. While in polluted air, peroxy radicals preferentially react with $\mathrm{NO}$; in pristine, low- $\mathrm{NO}_{x}$ conditions over the rainforest, e.g., in the Amazon, isoprene degradation leads to hydroxyhydroperoxides, which can reform $\mathrm{OH}$ upon further oxidation (Paulot et al., 2009).

An important pathway in isoprene chemistry, basic to the recycling of $\mathrm{OH}$, is isomerization through $\mathrm{H}$ migration within oxygenated reaction products, leading to photolabile hydroperoxyaldehydes (HPALD), as reviewed by Vereecken and Francisco (2012). While a high rate of 1,5-H shifts that we have assumed previously (Taraborrelli et al., 2012) was not confirmed experimentally, these and especially $1,4-\mathrm{H}$ and 1,6-H shifts have nevertheless been shown to be key intermediaries in OH recycling (Crounse et al., 2012, 2013; Fuchs et al., 2014; Peeters et al., 2014). When the OH concentration is low, its formation is maintained by photodissociation of HPALD, while at high $\mathrm{OH}$ concentration its sink reaction with HPALD gains importance. Next to HPALD, unsaturated hydroperoxyaldehydes, e.g., peroxyacylaldehydes (PACALD), were shown to be relevant (Peeters et al., 2014). Higher-generation reaction products include several organic peroxides that produce $\mathrm{OH}$ upon photodissociation, which need to be accounted for in atmospheric chemistry models to reproduce field and reaction chamber observations (Nölscher et al., 2014).

These reactions have been included in MOM, being an extension and update of the Mainz Isoprene Mechanism, v.2 (Taraborrelli et al., 2009, 2012). The scheme, which accounts for about 630 compounds and 1630 reactions, makes use of rate constant estimation methods similarly to the Master Chemical Mechanism by Jenkin et al. (2015) (http: $/ / \mathrm{mcm}$.leeds.ac.uk/MCM) and recommendations by the Task Group on Atmospheric Chemical Kinetic Data Evaluation (http://iupac.pole-ether.fr), in addition to our own evalua- tion of the recent literature. For the present work we applied the full scheme, also used by Cabrera-Perez et al. (2016), which is computationally demanding and precludes us applying high spatial resolution of the model for extended time periods. For computational efficiency in global and regional models, the scheme will be condensed in the future. In contrast to some previous chemistry mechanisms in atmospheric models, MOM accounts for higher-generation reaction products and is mass-conserving (notably for carbon-containing reaction products from VOC oxidation).

MOM has been included in the EMAC general circulation model. The core atmospheric general circulation model is ECHAM5 (Roeckner et al., 2006), coupled with the Modular Earth Submodel System, of which we have applied MESSy2 version 2.42 (Jöckel et al., 2010). For this study EMAC was used in a chemical-transport model (CTM mode) (Deckert et al. 2011), i.e., by disabling feedbacks between photochemistry and dynamics. EMAC submodels represent tropospheric and stratospheric processes and their interaction with oceans, land and human influences, and they describe emissions, radiative processes, atmospheric multiphase chemistry, aerosol and deposition mechanisms (Jöckel et al., 2005, 2006; Sander et al., 2005, 2011, 2014; Kerkweg et al., 2006; Tost et al., 2006, 2007a; Pozzer et al., 2007, 2011; Pringle et al., 2010). We applied the EMAC model at T42/L31 spatial resolution, i.e., at a spherical spectral truncation of T42 and a quadratic Gaussian grid spacing of about $2.8^{\circ}$ latitude and longitude, and 31 hybrid terrain-following pressure levels up to $10 \mathrm{hPa}$.

Results have been evaluated against observations (Pozzer et al., 2010, 2012; de Meij et al., 2012; Christoudias and Lelieveld, 2013; Elshorbany et al., 2014; Yoon and Pozzer, 2014; Cabrera-Perez et al., 2016; for additional references, see http://www.messy-interface.org). Here we present results based on emission fluxes and meteorology representative of the year 2013, mostly annual means unless specifically mentioned otherwise. Tests of the present model version indicate minor changes, e.g., in intermediately long lived compounds such as $\mathrm{O}_{3}$ and $\mathrm{CO}$, compared to previous versions. $\mathrm{N}_{2} \mathrm{O}$ and $\mathrm{CH}_{4}$ concentrations have been prescribed at the surface based on observations. Anthropogenic emissions have been based on the RCP8.5 emission scenario (Riahi et al., 2007; van Vuuren et al., 2011; Meinshausen et al., 2011). The scenario was tested by Granier et al. (2011), indicating that it realistically represents the source strengths of pollutants after the year 2000. The RCP8.5 scenario was also applied by Cabrera-Perez et al. (2016), in which the emissions and chemistry of aromatic compounds was described. Natural emissions of higher VOCs are interactively calculated, amounting to $760 \mathrm{TgC} \mathrm{yr}^{-1}$, with a 4year range of $747-789 \mathrm{TgC} \mathrm{yr}^{-1}$ (including about $73 \%$, or $546-578 \mathrm{TgC} \mathrm{yr}^{-1}$, of isoprene) (Guenther et al., 2012), and anthropogenic emissions of saturated, unsaturated and aromatic compounds amount to $105 \mathrm{TgC} \mathrm{yr}^{-1}$. These flux integrals are in carbon equivalent. It should be mentioned that in 
previous-generation atmospheric chemistry-transport models VOC emissions have been artificially reduced to prevent the collapse of $\mathrm{OH}$ concentrations in regions of strong natural sources, i.e., at high-VOC and low- $\mathrm{NO}_{x}$ conditions (Arneth et al., 2010).

To analyze model production and sink pathways of $\mathrm{OH}$ and $\mathrm{HO}_{2}$, including multiple radical recycling, and compute fluxes of reactants and intermediate products, we used the kinetic chemistry tagging technique of Gromov et al. (2010). The scheme computes detailed turnover rates of selected tracers, in this case $\mathrm{OH}, \mathrm{HO}_{2}, \mathrm{O}_{3}, \mathrm{CO}$, aldehydes, peroxides and others, in various parts of the MOM chemistry scheme within EMAC. With limited additional computational load the extensive budgeting allows characterization of $\mathrm{OH}$ sources and sinks, while the diagnostic calculations are decoupled from the regular chemistry scheme.

Here we present a selection of results, focusing on annual and large-scale averages to characterize global $\mathrm{OH}$. The Supplement presents supporting tables and figures for the interested reader. Pages S1-S14 illustrate time sequences (Hovmöller plots), seasonal differences and results for different atmospheric environments and reservoirs such as the $\mathrm{BL}$ and FT, to distinguish continental from marine boundary layers (CBLs and MBLs), the lower troposphere from the tropopause region and the lower stratosphere. These supplementary results focus on distributions of $\mathrm{OH}$ and $\mathrm{HO}_{2}$ as well as lifetimes of different species - notably $\mathrm{OH}, \mathrm{HO}_{2}, \mathrm{CO}$ and $\mathrm{CH}_{4}$ - and include figures of global $\mathrm{OH}$ reactivity which are relevant for the discussion in Sect. 5. Page S15 presents details on the global $\mathrm{OH}$ budget, relevant for Sect. 6. The Supplement also includes scatterplots between observations and model results of $\mathrm{CO}$ and $\mathrm{O}_{3}$ at the surface for the year 2013 (p. S16); a table with details of VOC emission fluxes applied in EMAC (p. S17); and the complete mechanism of MOM, including a list of all chemical species (p. S18 and following). Model-calculated global datasets of $\mathrm{OH}$ concentrations and other trace gases are available upon request.

\section{Global OH distribution}

In agreement with previous studies our model calculations show highest $\mathrm{OH}$ concentrations in the tropical troposphere (Fig. 1). Globally, mean tropospheric $\mathrm{OH}$ is $11.3 \times 10^{5}$ molecules $\mathrm{cm}^{-3}$, close to the multimodel mean of $11.1 \pm 1.6 \times 10^{5}$ molecules $\mathrm{cm}^{-3}$ derived by Naik et al. (2013) for the year 2000. Note that these are volume-weighted means. Following the recommendation by Lawrence et al. (2001), we also calculated the air-mass-weighted $\left(11.1 \times 10^{5}\right.$ molecules $\left.\mathrm{cm}^{-3}\right), \mathrm{CH}_{4}$ weighted $\left(12.4 \times 10^{5}\right.$ molecules $\left.\mathrm{cm}^{-3}\right)$ and methyl chloroform $(\mathrm{MCF})$-weighted means $\left(12.3 \times 10^{5}\right.$ molecules $\left.\mathrm{cm}^{-3}\right)$, though henceforth we primarily report volume-weighted mean values.
The calculated tropical tropospheric average is $14.6 \times 10^{5}$ molecules $\mathrm{cm}^{-3}$ (between the tropics of Cancer and Capricorn), with the $\mathrm{NH}$ and $\mathrm{SH}$ extratropical averages being 9.1 and $6.6 \times 10^{5}$ molecules $\mathrm{cm}^{-3}$, respectively. Our model indicates more $\mathrm{OH}$ north of the Equator compared to the south of it, $12.1 \times 10^{5}$ and $10.1 \times 10^{5}$ molecules $\mathrm{cm}^{-3}$, respectively. Hence the $\mathrm{NH} / \mathrm{SH}$ ratio is 1.20 , being towards the low end of the multimodel estimate of $1.28 \pm 0.10$ by Naik et al. (2013), though deviating from interhemispheric parity derived by Patra et al. (2014) based on the analysis of $\operatorname{MCF}\left(\mathrm{CH}_{3} \mathrm{CCl}_{3}\right)$ measurements.

For the air-mass-, $\mathrm{CH}_{4}$ - and MCF-weighted means we find $\mathrm{NH} / \mathrm{SH}$ ratios of $1.25,1.30$ and 1.25 , respectively. Part of the discrepancy with Patra et al. (2014) may be related to the seasonally varying position of the Intertropical Convergence Zone (ITCZ), which effectively separates the meteorological $\mathrm{NH}$ from the SH. The position of the ITCZ, on average a few degrees north of the Equator in the region of highest $\mathrm{OH}$, can influence these calculations, both in models and MCF analyses. If we correct for this, the volume-weighted $\mathrm{NH} / \mathrm{SH}$ ratio of $\mathrm{OH}$ decreases from 1.20 to 1.13. In the extratropics our model calculates $28 \%$ less $\mathrm{OH}$ in the $\mathrm{SH}$ compared to the $\mathrm{NH}$, which is the main reason for the model-calculated interhemispheric $\mathrm{OH}$ difference. The asymmetry is larger between the Arctic and Antarctic regions (defined by the polar circles), as the calculated mean $\mathrm{OH}$ concentration is $50 \%$ lower in the latter. However, if we also include the lower stratosphere (up to $10 \mathrm{hPa}$ ), we find near-interhemispheric parity of $\mathrm{OH}$, i.e., $5 \%$ more in the $\mathrm{NH}$ and only $2 \%$ more based on the ITCZ metric. Considering the importance of the stratosphere as an MCF reservoir to the troposphere in recent years (Krol and Lelieveld, 2003), and possible interhemispheric differences in the age of air in the middle atmosphere, these aspects should be investigated further with a model version that accounts for the atmosphere from the surface to the mesosphere, to investigate the importance for $\mathrm{MCF}$ analyses and inferred $\mathrm{OH}$ distributions.

Figure 1 illustrates that high $\mathrm{OH}$ concentrations in the tropics can extend up to the tropopause, with a main $\mathrm{OH}$ maximum below $300-400 \mathrm{hPa}$ and a second maximum between 200 and $150 \mathrm{hPa}$. Note that the tropopause in the tropics is defined using temperature and in the extratropics using potential vorticity gradients ( $2 \mathrm{PV}$ units). The oxidative conditions throughout the tropical troposphere limit the flux of reduced and partly oxidized gases (e.g., reactive halocarbons, sulfur and nitrogen gases) into the stratosphere through their chemical conversion into products that are removed by deposition processes. Near the cold tropical tropopause, reaction products, such as low-volatility acids, can be removed by adsorption to sedimenting ice particles that also dehydrate the air that ascends into the stratosphere (Lelieveld et al., 2007). Due to the slow ascent rates of air parcels in the tropical tropopause region (tropical transition layer), pollutant gases are extensively exposed to oxidation by $\mathrm{OH}$ for several weeks to months. This mechanism protects the ozone layer from 


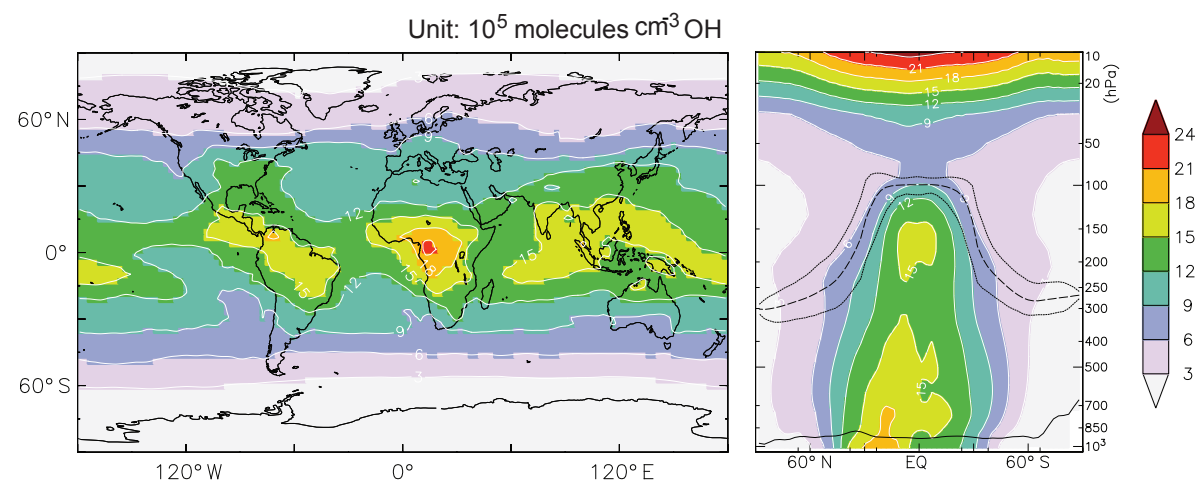

Figure 1. Global $\mathrm{OH}$ in $10^{5}$ molecules $\mathrm{cm}^{-3}$. Left: tropospheric, annual mean. Right: zonal annual mean up to $10 \mathrm{hPa}$. The lower solid line indicates the average boundary layer height, the upper dashed line the mean tropopause and the solid lines the annual minimum and maximum tropopause height.

$\mathrm{O}_{3}$-depleting substances that could be transported from the troposphere, at least to the extent that they react with $\mathrm{OH}$.

In the global troposphere, annual column average $\mathrm{OH}$ ranges from $1.0 \times 10^{5}$ to $22.0 \times 10^{5}$ molecules $\mathrm{cm}^{-3}$, i.e., between high and low latitudes, respectively (Fig. 1). This range is determined by the meridional $\mathrm{OH}$ gradient in the FT, since about $85 \%$ of tropospheric $\mathrm{OH}$ formation takes place in the FT, which thus dominates the global $\mathrm{OH}$ distribution (detailed below). In the BL the range is much larger, $0.3 \times 10^{5}$ to $44.0 \times 10^{5}$ molecules $\mathrm{cm}^{-3}$, as $\mathrm{OH}$ is more strongly affected by variable surface emissions. The subordinate role of the $\mathrm{BL}$ in the global $\mathrm{OH}$ load and distribution is conspicuous, for example from the $\mathrm{OH}$ maximum in the $\mathrm{BL}$ over the Middle East and $\mathrm{OH}$ minima over the central African and Amazon forests (Fig. S1 of the Supplement), which do not appear in the tropospheric column average $\mathrm{OH}$ concentrations, as the latter follow the $\mathrm{OH}$ distribution in the FT (Fig. 1).

In the BL over tropical forests $\mathrm{OH}$ concentrations are comparatively low, about $10 \times 10^{5}$ to $20 \times 10^{5}$ molecules $\mathrm{cm}^{-3}$, in agreement with $\mathrm{OH}$ measurements in South America and southeastern Asia (Kubistin et al., 2010; Pugh et al., 2010; Whalley et al., 2011), while in the FT in these regions OH concentrations are several times higher. The relatively high $\mathrm{OH}$ in the tropical FT is related to the combination of emissions from vegetation with $\mathrm{NO}_{x}$ from lightning in deep thunderstorm clouds. This is most prominent over central Africa, where deep convection and lightning are relatively intense (Fig. 1, left panel). The latter was corroborated by comparing our model with lightning observations (Tost et al., 2007b). The chemical mechanisms that control $\mathrm{OH}$ in the BL and FT are connected through vertical transport and mixing, which balance formation and loss in the column; i.e., near the surface VOCs are a net sink of $\mathrm{OH}$, while their reaction products are a net $\mathrm{OH}$ source aloft.

In the $\mathrm{NH}$ extratropics mean $\mathrm{OH}$ in the MBL approximately equals that in the CBL, i.e., in the zonal direction. As shown previously, this is related to the transport and mix- ing of oxidants (primarily $\mathrm{O}_{3}$ ) and precursor gases (e.g., $\mathrm{NO}_{x}$ and partially oxidized volatile organic compounds) from polluted regions across the Atlantic and Pacific oceans (Lelieveld et al., 2002). In the SH, on the other hand, where anthropogenic $\mathrm{NO}_{x}$ sources and related transports are much weaker, mean $\mathrm{OH}$ in the $\mathrm{CBL}$ is about $15 \%$ higher compared to the MBL. In the extratropical troposphere as a whole, $\mathrm{OH}$ gradients in the longitudinal direction are typically small (Fig. 1), related to relatively rapid exchanges by zonal winds in transient synoptic weather systems.

While primary $\mathrm{OH}$ formation (Reactions $\mathrm{R} 1, \mathrm{R} 2$ ) during daytime is controlled by photodissociation of $\mathrm{O}_{3}$, there are additional sources that can be relevant at night. This includes reactions of $\mathrm{O}_{3}$ with unsaturated hydrocarbons and aromatic compounds in polluted air and with terpenes emitted by vegetation. Figure 2 shows nighttime $\mathrm{OH}$ in the boundary layer during January and July to illustrate the strong seasonal dependency. While the color coding is the same as Fig. 1, the concentrations are scaled by a factor of 20. On a global scale, $\mathrm{OH}$ concentrations in the BL at night are nearly 2 orders of magnitude lower than during the day, and in the FT diel differences are even larger. Therefore, nighttime $\mathrm{OH}$ does not significantly influence the atmospheric oxidation capacity and the lifetimes of $\mathrm{CH}_{4}$ and $\mathrm{CO}$. Nevertheless, Fig. 2 shows several hot spots, mostly in the subtropical BL in the $\mathrm{NH}$ during summer, where nighttime $\mathrm{OH}$ can exceed $10^{5}$ molecules $\mathrm{cm}^{-3}$ and could contribute to chemical processes, such as new particle formation. These regions include the western USA, the Mediterranean and Middle East, the Indo-Gangetic Plain and eastern China.

\section{Global HO $\mathrm{HO}_{x}$ distribution}

Since conversions between $\mathrm{HO}_{2}$ and $\mathrm{OH}$ play a key role in $\mathrm{OH}$ recycling, we address the budget of $\mathrm{HO}_{x}\left(\mathrm{OH}+\mathrm{HO}_{2}\right)$, which is dominated by $\mathrm{HO}_{2}$. Field and laboratory measurements often address both $\mathrm{OH}$ and $\mathrm{HO}_{2}$. Figure 3 shows 


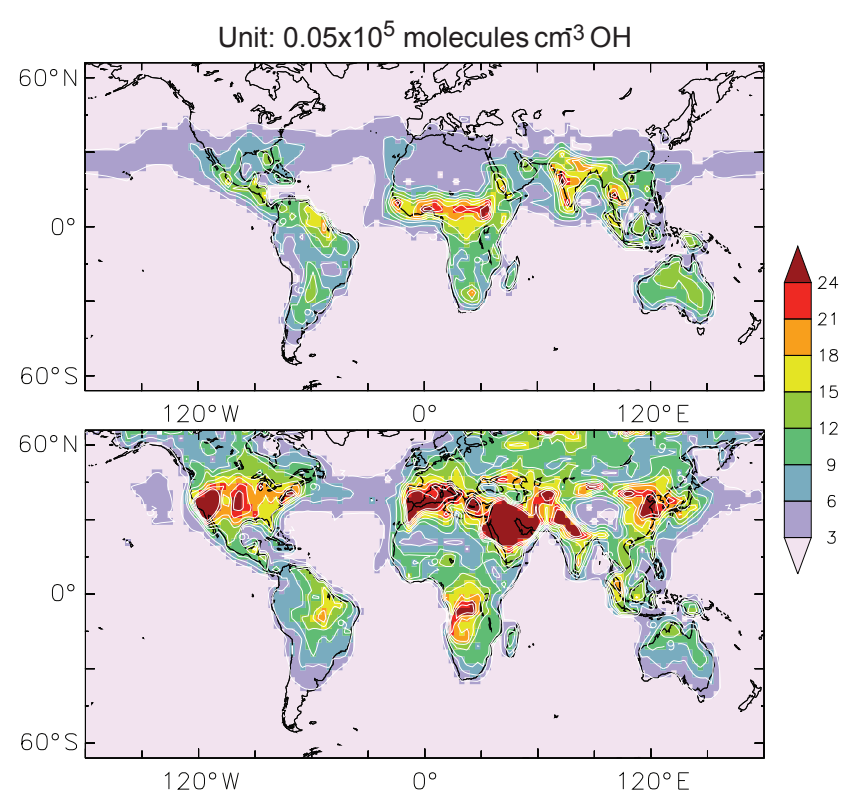

Figure 2. Nighttime $\mathrm{OH}$ in the boundary layer in January (top) and July (bottom). Color coding is the same as Fig. 1, but concentrations are scaled by a factor of $20\left(\times 0.05 \times 10^{5}\right.$ molecules $\left.\mathrm{cm}^{-3}\right)$.

the annual $\mathrm{HO}_{2}$ concentration distribution, the counterpart of $\mathrm{OH}$ in Fig. 1. We find that in the $\mathrm{BL}$ annual mean $\mathrm{HO}_{2}$ ranges from 0.1 to $6.4 \times 10^{8}$ molecules $\mathrm{cm}^{-3}$ globally, whereas in the FT as a whole this is only 0.2 to $1.1 \times 10^{8}$ molecules $\mathrm{cm}^{-3}$. Even though the mean lifetime of $\mathrm{HO}_{2}$ in the troposphere of $1.5 \mathrm{~min}$ is much longer than of $\mathrm{OH}$ (factor of 60), both $\mathrm{OH}$ and $\mathrm{HO}_{2}$ are locally controlled by chemistry. Transport processes influence $\mathrm{HO}_{x}$ through longer-lived precursor and reservoir species such as $\mathrm{O}_{3}$ and OVOCs. Whereas $\mathrm{OH}$ in the BL over the tropical forests is relatively low, $\mathrm{HO}_{2}$ is relatively high, about $5 \times 10^{8}$ molecules $\mathrm{cm}^{-3}$, i.e., 2 to 3 orders of magnitude higher than $\mathrm{OH}$, consistent with observations (Kubistin et al., 2010). Our results suggest that from a global perspective $\mathrm{HO}_{x}$ is highest over the tropical forests, where photochemistry is very active and $\mathrm{OH}$ sources and sinks are large. Localized $\mathrm{HO}_{x}$ maxima are also found in the polluted CBL, where reactive $\mathrm{VOC}$ and $\mathrm{NO}_{x}$ emissions are strong, e.g., by the petroleum industry north of the Mexican Gulf and near the Persian Gulf (Ren et al., 2013; Lelieveld et al., 2009).

On a global scale the tropospheric production of $\mathrm{HO}_{x}$ is dominated by that in the FT. In the FT $\mathrm{HO}_{x}$ is subject to long-range transport of relatively long lived source and sink gases such as $\mathrm{O}_{3}$ and $\mathrm{CO}$, whereby the latter redistributes $\mathrm{OH}$ into $\mathrm{HO}_{2}$ within $\mathrm{HO}_{x}$, whereas in the $\mathrm{BL}$ local emissions of short-lived VOCs and $\mathrm{NO}_{x}$ are more relevant. The efficient atmospheric transport of longer-lived gases, such as $\mathrm{O}_{3}$ from both the stratosphere and photochemically polluted regions, helps buffer the $\mathrm{OH}$ formation in regions where oxidant is depleted, such as the MBL (Lelieveld and Dentener, 2000; de
Laat and Lelieveld, 2000). Within the tropospheric column, convection and entrainment of $\mathrm{O}_{3}$-rich air from the FT into the BL play a key role in the exchange of oxidant, which reduces vertical gradients, and balances $\mathrm{HO}_{x}$ production and loss processes across altitudes.

We calculate a global tropospheric average $\mathrm{HO}_{2}$ concentration of $0.6 \times 10^{8}$ molecules $\mathrm{cm}^{-3}$. We find roughly the same average concentrations in the tropical and $\mathrm{NH}$ extratropical troposphere, and slightly less in the SH extratropics $\left(0.5 \times 10^{8}\right.$ molecules $\left.\mathrm{cm}^{-3}\right)$. Thus the mean tropospheric $\mathrm{HO}_{2}$ (and $\mathrm{HO}_{x}$ ) concentrations in these tropical and extratropical reservoirs are very similar. Nevertheless, in the $\mathrm{SH}$ the mean $\mathrm{HO}_{2}$ concentration in the $\mathrm{CBL}$ is about a factor of 2 higher compared to the MBL, associated with strong VOC emissions by vegetation subject to intense photochemistry. In the $\mathrm{NH}$ mean $\mathrm{HO}_{2}$ is comparable between the MBL and $\mathrm{CBL}$, due to the widespread impact of air pollution, as explained above. The seasonal differences in tropospheric $\mathrm{HO}_{x}$ at middle and high latitudes can be large though, i.e., about an order of magnitude between summer and winter. The seasonality of primary $\mathrm{OH}$ formation, which is proportional to solar radiation intensity, is even larger. In Sect. 6 we discuss that the low primary formation in winter is partly compensated for by secondary $\mathrm{OH}$ formation, being less dependent on sunlight, which reduces latitudinal and seasonal $\mathrm{OH}$ contrasts.

\section{Trace gas lifetimes and $\mathrm{OH}$ reactivity}

The average tropospheric lifetime of $\mathrm{OH}\left(\tau_{\mathrm{OH}}\right)$ is $1.5 \mathrm{~s}$, calculated by dividing the annual averages of the volume-weighted $\mathrm{OH}$ burden and the total photochemical sink rate. Figure 4 presents the spatial distribution of $\tau_{\mathrm{OH}}$. Unlike the $\mathrm{OH}$ concentration, $\tau_{\mathrm{OH}}$ does not exhibit a strong seasonal cycle, being nearly absent in the tropics and the FT. Only in the CBL over Siberia, around $60^{\circ} \mathrm{N}$, can seasonal differences reach a factor of 5, related to the annual variability of VOC emissions by boreal forest (Siberian taiga). The tropospheric mean $\tau_{\mathrm{OH}}$ in the NH is $1.4 \mathrm{~s}$, and in the SH $1.6 \mathrm{~s}$. In the MBL mean $\tau_{\mathrm{OH}}$ is about $0.7 \mathrm{~s}$, in the CBL about $0.3 \mathrm{~s}$. The longest $\tau_{\mathrm{OH}}$ is found near the tropical tropopause (10-20 s), where $\mathrm{OH}$ reactivity (the inverse of $\tau_{\mathrm{OH}}$ ) is thus below $0.1 \mathrm{~s}^{-1}$. While this is largely related to low temperatures and reduced reaction rates, it also indicates that air masses that traverse the tropical transition layer into the stratosphere are cleansed from reactive compounds that are removed by $\mathrm{OH}$, which is important for organohalogen compounds, for example, that could damage the ozone layer. In the $\mathrm{NH}$ mean tropospheric $\mathrm{OH}$ reactivity is $0.7 \mathrm{~s}^{-1}$, and in the $\mathrm{SH} 0.6 \mathrm{~s}^{-1}$. The seasonality of $\tau_{\mathrm{HO}_{2}}$ is more pronounced than that of $\tau_{\mathrm{OH}} ; \tau_{\mathrm{HO}_{2}}$ is longest in the cold season and over Antarctica, up to $10 \mathrm{~min}$. In the MBL $\tau_{\mathrm{HO}_{2}}$ is on average $1.3 \mathrm{~min}$, in the CBL 0.5 and in the FT $1.7 \mathrm{~min}$. 


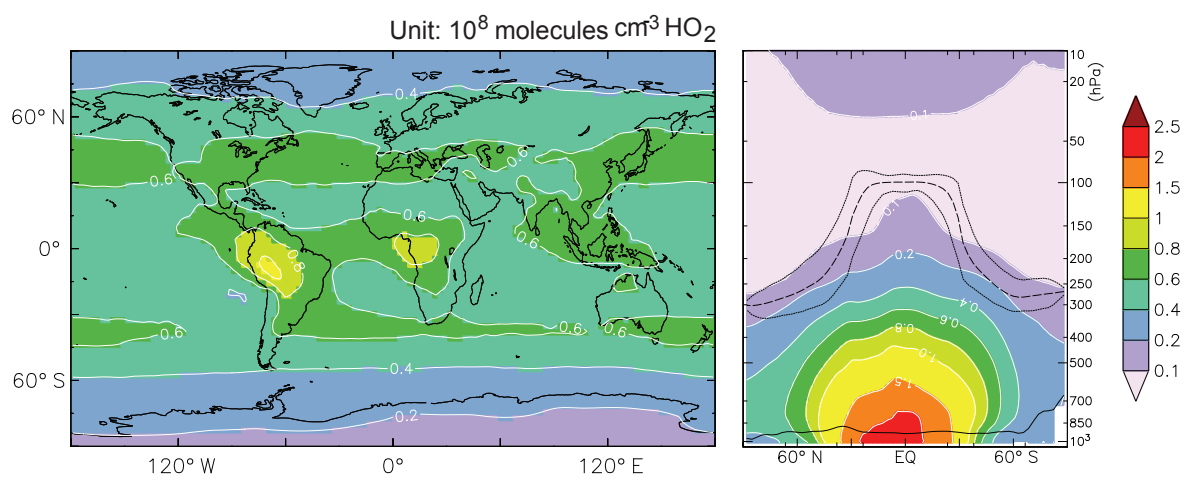

Figure 3. As Fig. 1 but for $\mathrm{HO}_{2}$ in $10^{8}$ molecules $\mathrm{cm}^{-3}$ in the troposphere (left) and up to $10 \mathrm{hPa}$ (right).

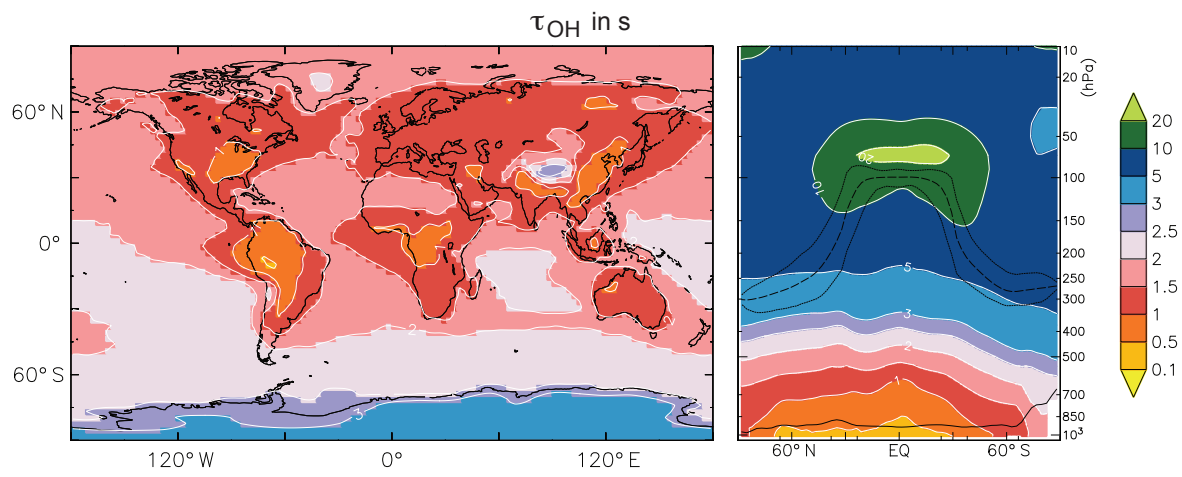

Figure 4. As Fig. 1 but for the $\mathrm{OH}$ lifetime ( $\tau_{\mathrm{OH}}$, seconds) in the troposphere (left) and up to $10 \mathrm{hPa}$ (right).

We find that $\tau_{\mathrm{OH}}$ is generally shortest over the tropical forest, followed by the boreal forest, coincident with the spatial distribution of total $\mathrm{OH}$ reactivity, i.e., the inverse of $\tau_{\mathrm{OH}}$, shown in Fig. 5. Near the Earth's surface the $\mathrm{OH}$ reactivity varies from about $0.5 \mathrm{~s}^{-1}$ over Antarctica, due to reaction of $\mathrm{OH}$ with $\mathrm{CH}_{4}$ and $\mathrm{CO}$ in clean and cold air, to approximately $100 \mathrm{~s}^{-1}$ over the Amazon rainforest in the dry season due to relatively strong isoprene sources, complemented by biomass burning emissions. This modeled $\mathrm{OH}$ reactivity range seems realistic in comparison to observations, whereas previous models - as well as measurement techniques - that did not account for all VOC reaction products and intermediates strongly underestimated $\mathrm{OH}$ reactivity, i.e., up to a factor of 10 (Whalley et al., 2011; Mogensen et al., 2015; Nölscher et al., 2016). This topic will be studied in greater detail in a follow-up publication where we address the reactive carbon budget in different environments, evaluated against measurements, where we also include secondary organic aerosols as described by Tsimpidi et al. (2016).

Our estimate of the mean lifetime of $\mathrm{CH}_{4}$ due to oxidation by tropospheric $\mathrm{OH}\left(\tau_{\mathrm{CH}_{4}}\right)$ is 8.5 years, which is within the multimodel-calculated $1 \sigma$ standard deviation of the mean of $9.7 \pm 1.5$ years presented by Naik et al. (2013), albeit towards the lower end of the range. Notice that this figure does not include uptake of $\mathrm{CH}_{4}$ by soils and stratospheric loss by $\mathrm{OH}$,
$\mathrm{O}\left({ }^{1} \mathrm{D}\right)$ and chlorine radicals, which together make up about $10 \%$ of the total $\mathrm{CH}_{4}$ sink. The 17 models that participated in the model intercomparison by Naik et al. (2013) show a range of 7.1-14.0 years, while the multimodel mean of 9.7 years was considered to be $5-10 \%$ higher than observation-derived estimates.

One reason for our $\tau_{\mathrm{CH}_{4}}$ estimate being toward the lower end of the range may be that Naik et al. (2013) refer to the year 2000, whereas we applied an emission inventory for the year 2010, i.e., after a period when $\mathrm{NO}_{x}$ concentrations increased particularly rapidly in Asia (Schneider and van der A, 2012) and CO concentrations decreased, most significantly in the Northern Hemisphere (Worden et al., 2013; Yoon and Pozzer, 2014). These trends in $\mathrm{NO}_{x}$ and $\mathrm{CO}$ may have contributed to a shift within $\mathrm{HO}_{x}$ from $\mathrm{HO}_{2}$ to $\mathrm{OH}$. Further, Naik et al. (2013) defined the tropospheric domain as extending from the surface up to $200 \mathrm{hPa}$, whereas we diagnose the tropopause height. In effect Naik et al. include part of the extratropical lower stratosphere, where $\tau_{\mathrm{CH}_{4}}$ is about a century. Another reason is that our MOM mechanism more efficiently recycles $\mathrm{OH}$ than other VOC chemistry schemes applied in global models. This is supported by our calculation of the MCF lifetime of 5.1 years, which compares with $5.7 \pm 0.9$ years by Naik et al. (2013), based on a range of 4.1-8.4 years among the 17 participating models. 

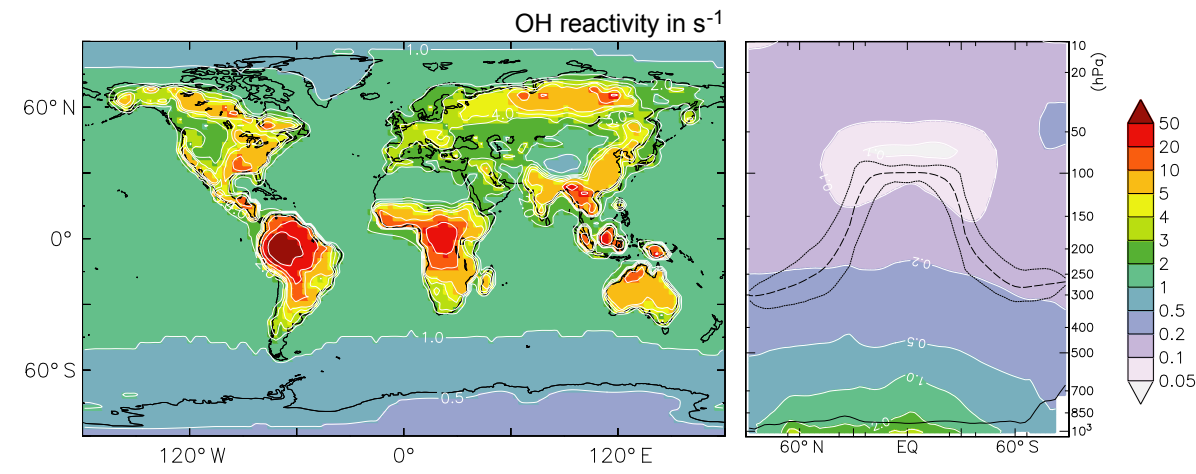

Figure 5. Annual mean $\mathrm{OH}$ reactivity near the Earth's surface in $\mathrm{s}^{-1}$.

We calculate that at the tropopause and the poles $\tau_{\mathrm{CH}_{4}}$ is longest, about a century. The mean $\tau_{\mathrm{CH}_{4}}$ in the extratropics is 13.8 years, and in the inner tropics 6.1 years. The mean $\tau_{\mathrm{CH}_{4}}$ in the BL is 4.9 , and in the FT 9.1 years. The effective range in the mean $\mathrm{OH}$ concentration and $\tau_{\mathrm{CH}_{4}}$ between the high- and the low-latitude troposphere is about a factor of 10 , which is close to the $\mathrm{OH}$ and $\mathrm{HO}_{2}$ range between the summer and winter at high latitudes. This is much smaller than the low-to-high-latitude gradients and the seasonal cycle of primary $\mathrm{OH}$ formation, indicative of the important role of secondary formation (Sect. 6). The $\mathrm{NH} / \mathrm{SH}$ ratio of $\tau_{\mathrm{CH}_{4}}$ is 0.77. Similar differences and latitude contrasts are found for the lifetime of tropospheric $\mathrm{CO}\left(\tau_{\mathrm{CO}}\right)$ due to reaction with OH. $\tau_{\mathrm{CO}}$ is on average about 38 days in the tropics, 65 days in the $\mathrm{NH}$ extratropics and 86 days in the $\mathrm{SH}$ extratropics, and the $\mathrm{NH} / \mathrm{SH}$ ratio of $\tau_{\mathrm{CO}}$ is 0.87 .

\section{Radical budget and recycling probability}

Figure 6 presents a summary of global annual mean $\mathrm{HO}_{x}$ production terms in the troposphere, also listed in Table 1 , which gives an overview of sources and sinks. Primary $\mathrm{OH}$ formation by Reactions (R1) and (R2) ( $P$, purple) amounts to $84 \mathrm{Tmol} \mathrm{yr}^{-1}$, of which about $85 \%$ takes place in the FT. We find that gross $\mathrm{OH}$ formation $(G)$ and $\mathrm{HO}_{2}$ production in the FT also account for about $85 \%$ of the tropospheric total. Secondary $\mathrm{OH}$ formation $(S)$ in the troposphere adds up to $167 \mathrm{Tmol} \mathrm{yr}^{-1}$, i.e., $67 \%$ of $G$, the latter being $251 \mathrm{Tmol} \mathrm{yr}^{-1}$. $S$ is subdivided into contributions by the $\mathrm{NO}_{x}$ mechanism (Reaction $\mathrm{R} 7$, blue); the $\mathrm{O}_{x}$ mechanism (Reactions R11 and R12; green and yellow, respectively); and the $\mathrm{OH}$ recycling in VOC chemistry, the OVOC mechanism (red). The result that $r>60 \%$ indicates that global OH is buffered, i.e., not sensitive to chemical perturbations. Figure 6 illustrates that the fractional contributions by the different production terms in the FT equal those in the troposphere as a whole. It is not surprising that the FT is the dominant reservoir in atmospheric oxidation as it contains 6-7 times more mass than the $\mathrm{BL}$, though it shows that $\mathrm{OH}$ formation
Table 1. Global, annual mean tropospheric source and sink fluxes of $\mathrm{OH}\left(\mathrm{Tmol} \mathrm{yr}^{-1}\right)$. Sources and sinks are also specified for the boundary layer and free troposphere.

\begin{tabular}{lrrr}
\hline Sources/sinks & $\mathrm{BL}$ & FT & Troposphere \\
\hline $\mathrm{O}\left({ }^{1} \mathrm{D}\right)+\mathrm{H}_{2} \mathrm{O}$ & 12.5 & 71.5 & $84.0(33 \%)$ \\
$\mathrm{NO}+\mathrm{HO}_{2}$ & 10.4 & 66.2 & $76.6(30 \%)$ \\
$\mathrm{O}_{3}+\mathrm{HO}_{2}$ & 3.5 & 30.9 & $34.4(14 \%)$ \\
$\mathrm{H}_{2} \mathrm{O}_{2}+h v$ & 2.3 & 22.5 & $24.8(10 \%)$ \\
$\mathrm{OVOC}, \mathrm{ROOH}+h v$ & 6.6 & 24.8 & $31.4(13 \%)$ \\
\hline Total OH sources & 35.3 & 215.9 & 251.2 \\
\hline $\mathrm{OH}+\mathrm{HO}_{y}^{1}$ & 4.8 & 41.4 & $46.2(18 \%)$ \\
$\mathrm{OH}+\mathrm{NO}_{y}^{2}$ & 0.8 & 3.3 & $4.1(1.5 \%)$ \\
$\mathrm{OH}+\mathrm{CH}_{4}$ & 4.1 & 25.7 & $29.8(12 \%)$ \\
$\mathrm{OH}+\mathrm{CO}_{\mathrm{OH}+\mathrm{other}_{1} \mathrm{VOC}^{3}}$ & 9.6 & 88.2 & $97.8(39 \%)$ \\
$\mathrm{OH}+\mathrm{C}_{2}+\mathrm{VOC}^{4}$ & 10.3 & 31.3 & $37.0(15 \%)$ \\
$\mathrm{Rest}$ & 0.4 & 1.2 & $1.6(0.5 \%)$ \\
\hline Total OH sinks & 35.7 & 215.5 & 251.2 \\
\hline
\end{tabular}

${ }^{1} \mathrm{H}_{2}, \mathrm{O}_{3}, \mathrm{H}_{2} \mathrm{O}_{2}$, radical-radical reactions. ${ }^{2} \mathrm{NO}, \mathrm{NO}_{2}, \mathrm{HNO}_{2}, \mathrm{HNO}_{3}$, $\mathrm{HNO}_{4}$, ammonia, $\mathrm{N}$-reaction products. ${ }^{3}$ VOC with one $\mathrm{C}$ atom (excl. $\mathrm{CH}_{4}$ ), incl. $\mathrm{CH}_{3} \mathrm{OH}, \mathrm{C}_{1}$-reaction products. ${ }^{4}$ VOC with $\geq 2 \mathrm{C}$ atoms, $\mathrm{C}_{2+}$-reaction products.

is rather evenly distributed between different environments within the troposphere, in spite of differences in precursors species and pollution levels.

On a global scale, the relative magnitudes of different $\mathrm{OH}$ production terms in the BL and FT are similar (Fig. 6), though the OVOC mechanism (red) is somewhat larger and the $\mathrm{O}_{x}$ mechanism (green and yellow) somewhat smaller than in the FT. The contribution by the $\mathrm{NO}_{x}$ mechanism, i.e., Reaction (R7) $\left(\mathrm{NO}+\mathrm{HO}_{2}\right.$, blue), is marginally smaller in the BL (30\%) than the FT (31\%), in spite of large areas in the BL being more directly influenced by anthropogenic $\mathrm{NO}_{x}$ emissions. As explained above, the contribution of $\mathrm{NO}_{x}$ to $\mathrm{OH}$ recycling can be locally self-limiting, e.g., in the strongly polluted $\mathrm{BL}$, while some $\mathrm{NO}_{x}$ - partly as reservoir gases 


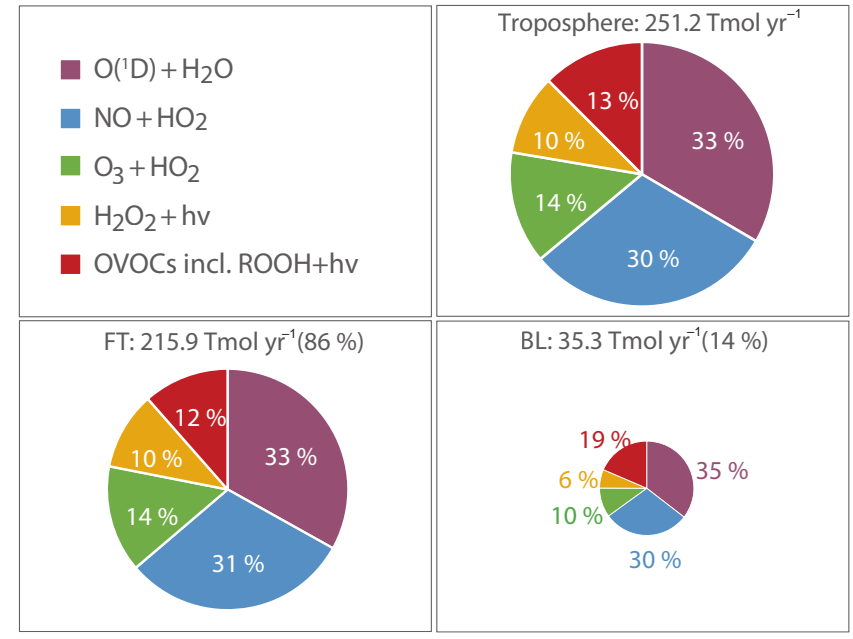

Figure 6. Main production terms of $\mathrm{OH}\left(\mathrm{Tmol} \mathrm{yr}^{-1}\right)$ in the troposphere (top right), free troposphere (bottom left) and boundary layer (bottom right). The sizes of the lower two graphs are proportional to the upper right graph, reflecting the percentages of $G$ in parentheses. We distinguish $P$ (purple) from $S$, the latter being made up of the $\mathrm{NO}_{x}$ mechanism (blue), the $\mathrm{O}_{x}$ mechanism (yellow and green) and the OVOC mechanism (red).

like organic nitrates - can escape to the FT, where relatively lower concentrations can be effective in $\mathrm{OH}$ production. Examples of $\mathrm{NO}_{x}$ reservoir gases in MOM are alkyl nitrates with carbonyls, e.g., nitro-oxyacetone (NOA) and the nitrate of methyl ethyl ketone.

By comparing gross $\mathrm{OH}$ formation $G$ between different regions, we find that it is about twice as high in the tropics as in the extratropics and $16 \%$ lower in the SH than the NH. The upper panel of Fig. 7 presents $G$ in ppbv day ${ }^{-1}$ (the lower panels $P$ and $S$ ), with a global annual average in the troposphere of $4.8 \mathrm{ppbv} \mathrm{day}^{-1}$. At low latitudes $G$ is much higher over continents than oceans, related to strong $\mathrm{OH}$ recycling, while at high latitudes longitudinal gradients are small, also between oceans and continents in the NH (Fig. 7). Since emissions that affect $\mathrm{OH}$ largely occur on land, the latter underscores that on a large scale $\mathrm{OH}$ is buffered through processes in the FT. Regional maxima of $G$ are found over the Amazon, central Africa and southeastern Asia, and smaller areas north of the Mexican Gulf in the USA, central America and Indonesia (Fig. 7). Over the Amazon and central Africa we find a relatively high $G$ up to the tropopause, related to deep convection and lightning $\mathrm{NO}_{x}$ over regions that are rich in natural VOCs. Within the BL $G$ can vary greatly, e.g., being on average more than 3 times larger in the CBL than in the MBL. Comparing $P$ between different regions, we find that it is $37 \%$ higher in the tropics compared to the subtropics, while on average it is the same over oceans and continents.

Consequently, average $S$ is also the same over oceans and continents, though below we underscore that the underlying chemical mechanisms can be very different. In the SH extratropics $P$ is about $40 \%$ lower than in the NH, mostly associated with the lower abundance of tropospheric $\mathrm{O}_{3}$ in the $\mathrm{SH}$. This interhemispheric asymmetry is manifest in the middle panels of Fig. 7. Comparison of the middle and lower panels in Fig. 7 shows that spatial gradients of $P$ and $S$ can be rather different, e.g., towards high latitudes with $P$ falling off with solar radiation and water vapor, while $P$ also declines with altitude. In these regions gradients of $S$ are weaker than those of $P$. This actually contributes to $\mathrm{OH}$ buffering, as the relatively low rate of $P$ is partly compensated for by $S$. This mechanism also acts seasonally; i.e., $S$ is more important in winter.

Rohrer and Berresheim (2006) and Rohrer et al. (2014) emphasized the tight linear relationship between tropospheric $\mathrm{OH}$ and UV radiation in Germany and China, expressed by measurements of $\mathrm{OH}$ and the photodissociation frequency of $\mathrm{O}_{3}\left(J\left(\mathrm{O}^{1} \mathrm{D}\right)\right)$. While the relationship with sunlight is also evident from our results, the interpretation is not straightforward because $P$ also depends on $\mathrm{O}_{3}$ and $\mathrm{H}_{2} \mathrm{O}$, and $S$ additionally depends on other factors. For example, in the tropics $P$ has a maximum in the lower troposphere and a minimum in the upper troposphere, where the UV intensity is higher, related to dependencies of the $J\left(\mathrm{O}^{1} \mathrm{D}\right)$ quantum yield and $\mathrm{H}_{2} \mathrm{O}$ on temperature. Hence the slope of the regression is different. Furthermore, $S$ is not contingent on $J\left(\mathrm{O}^{1} \mathrm{D}\right)$ and is generally less strongly dependent on solar radiation.

This is illustrated by Fig. 8, indicating that sometimes a tight linear relationship with $J\left(\mathrm{O}^{1} \mathrm{D}\right)$ is found, e.g., for $P$ in the BL, but that the relationship with $S$ in the BL is less compact, while in the FT $S$ can deviate from linearity at low UV intensity. Based on a global sample size of 1.45 million pairs from our model calculations, we find a high correlation $\left(R^{2}=0.94\right)$ between $P$ and $J\left(\mathrm{O}^{1} \mathrm{D}\right)$ and a lower correlation $\left(R^{2}=0.80\right)$ between $S$ and $J\left(\mathrm{O}^{1} \mathrm{D}\right)$. While the mean slope for $P$ is 0.99 (intercept close to 0 ), it is 0.46 for $S$ (intercept of about 0.3 ). Therefore, there is no unique relationship between $\mathrm{OH}$ and $\mathrm{UV}$ radiation as it depends on the relative importance of $P, S$ and the different mechanisms that contribute to $S$.

Figure 9 illustrates the efficiency at which $\mathrm{OH}$ is recycled, i.e., the recycling probability $r=1-P / G$. We find relatively large differences between tropospheric reservoirs, e.g., between the CBL and MBL, and also between the tropics and extratropics. When $S$ is smaller than $P, r$ is below $50 \%$ (yellow). However, if we consider the troposphere as a whole, $S$ exceeds $P$ everywhere due to the predominance of $\mathrm{OH}$ recycling in the FT. In the low-latitude MBL $r$ is lowest, indicative of a relatively high sensitivity to perturbations such as large-scale variations and trends in $\mathrm{CH}_{4}$ and $\mathrm{CO}$. This is not the case in the continental troposphere, where natural VOCs play an important role in $\mathrm{OH}$ recycling. Figure 9 shows that $r$ is larger in the extratropics than in the tropics and largest at high latitudes. 


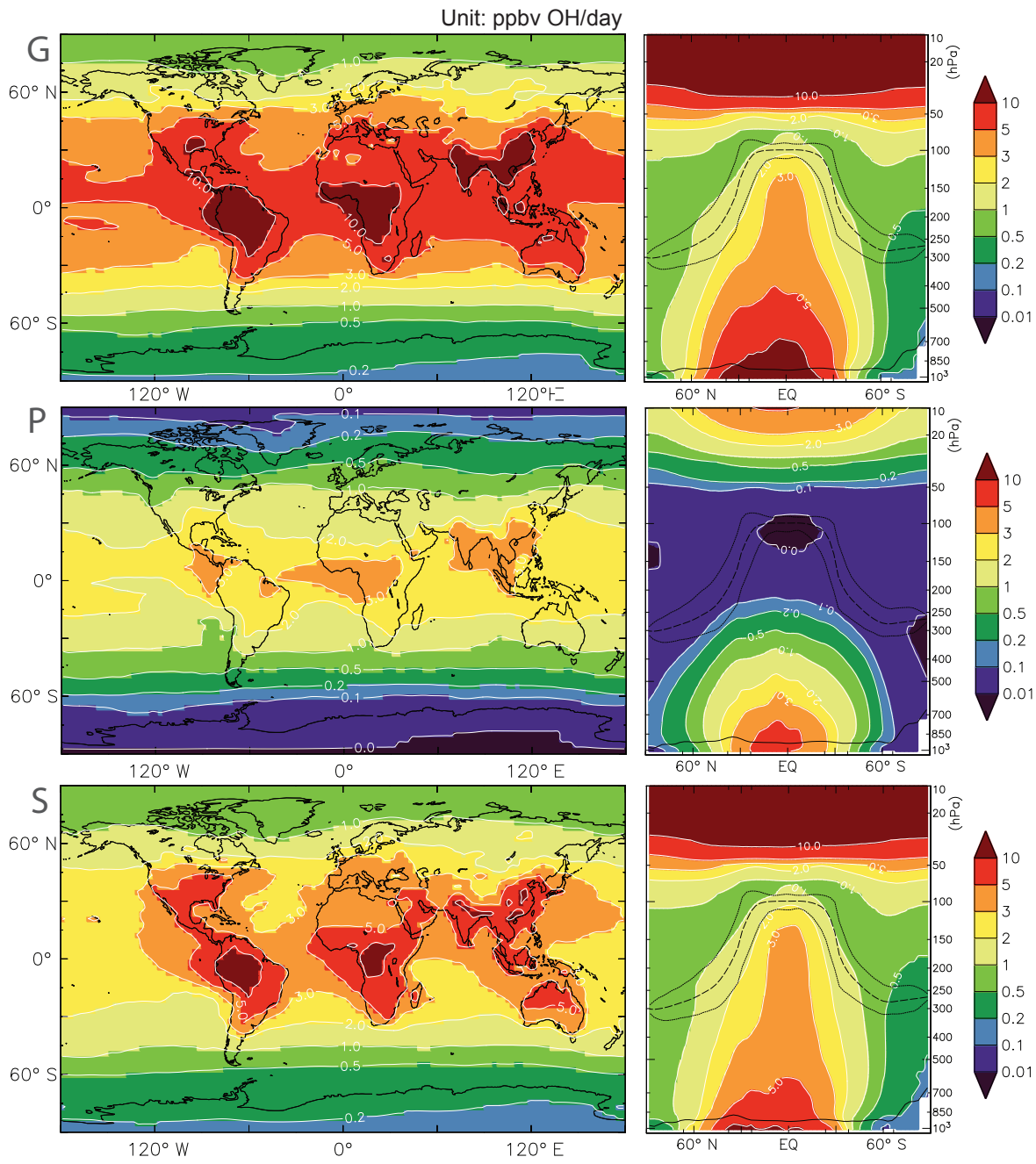

Figure 7. Annual mean $\mathrm{OH}$ formation in the troposphere (left) and up to $10 \mathrm{hPa}$ (right). The top panels show total $(G)$, the middle panels primary $(P)$ and the bottom panels secondary $(S)$ OH formation (in ppbv day ${ }^{-1}$ ).

The chemical buffering mechanisms include the dominant though self-limiting effect of $\mathrm{NO}_{x}$ on $\mathrm{OH}$ formation in polluted air, the latter through Reaction (R10), which is an important sink of both $\mathrm{NO}_{2}$ and $\mathrm{OH}$ when concentrations are high $\left(\mathrm{NO}_{x}\right.$ mechanism; blue in Fig. 6). In unpolluted, low$\mathrm{NO}_{x}$ conditions the OVOC mechanism acts through competition of unsaturated peroxide and carbonyl sinks, e.g., HPALD in isoprene chemistry (red in Fig. 6). When $\mathrm{OH}$ is high, HPALD reacts with $\mathrm{OH}$, whereas at low $\mathrm{OH}$ photodissociation takes the upper hand through the formation of PACALD, which produces $\mathrm{OH}$. Over land $\mathrm{OH}$ is generally buffered by the $\mathrm{NO}_{x}$ and OVOC mechanisms, illustrated by values of $r$ well over $50 \%$ (Fig. 9). However, remote from $\mathrm{NO}_{x}$ and VOC sources in the BL over the tropical and subtropical oceans $r$ can be below $40 \%$. In these environments $\mathrm{OH}$ recycling depends on the $\mathrm{O}_{x}$ mechanism (green plus yellow in Fig. 6), which has limited efficiency because Reaction (R11) $\left(\mathrm{O}_{3}+\mathrm{HO}_{2}\right)$ is a net oxidant sink. Hence the $\mathrm{O}_{x}$ mechanism depends on replenishment of $\mathrm{O}_{3}$ through transport in the FT and subsequent mixing into the BL.

Differences in $S$ between tropospheric reservoirs - e.g., the CBL, MBL, tropics and extratropics - are associated with these three principal $\mathrm{OH}$ recycling mechanisms, to various degrees related to natural and anthropogenic $\mathrm{VOC}$ and $\mathrm{NO}_{x}$ emissions. Figure 10 illustrates how $\mathrm{OH}$ is buffered both on local and global scales. It shows the fractional contributions of the $\mathrm{NO}_{x}, \mathrm{O}_{x}$ and OVOC mechanisms to the overall recycling probability $r$, and it indicates that the three mechanisms are complementary. The $\mathrm{NO}_{x}$ mechanism dominates in the $\mathrm{NH}$, especially in polluted air at middle latitudes, and most strongly over the continents. In the $\mathrm{SH}$ over the continents, in low- $\mathrm{NO}_{x}$ air, the OVOC mechanism dominates. In the marine environment - except the pollution outflow regions over the Atlantic and Pacific oceans - the $\mathrm{O}_{x}$ mechanism predominates. Seasonal complementarity of the three mechanisms is most significant at high latitudes, especially 

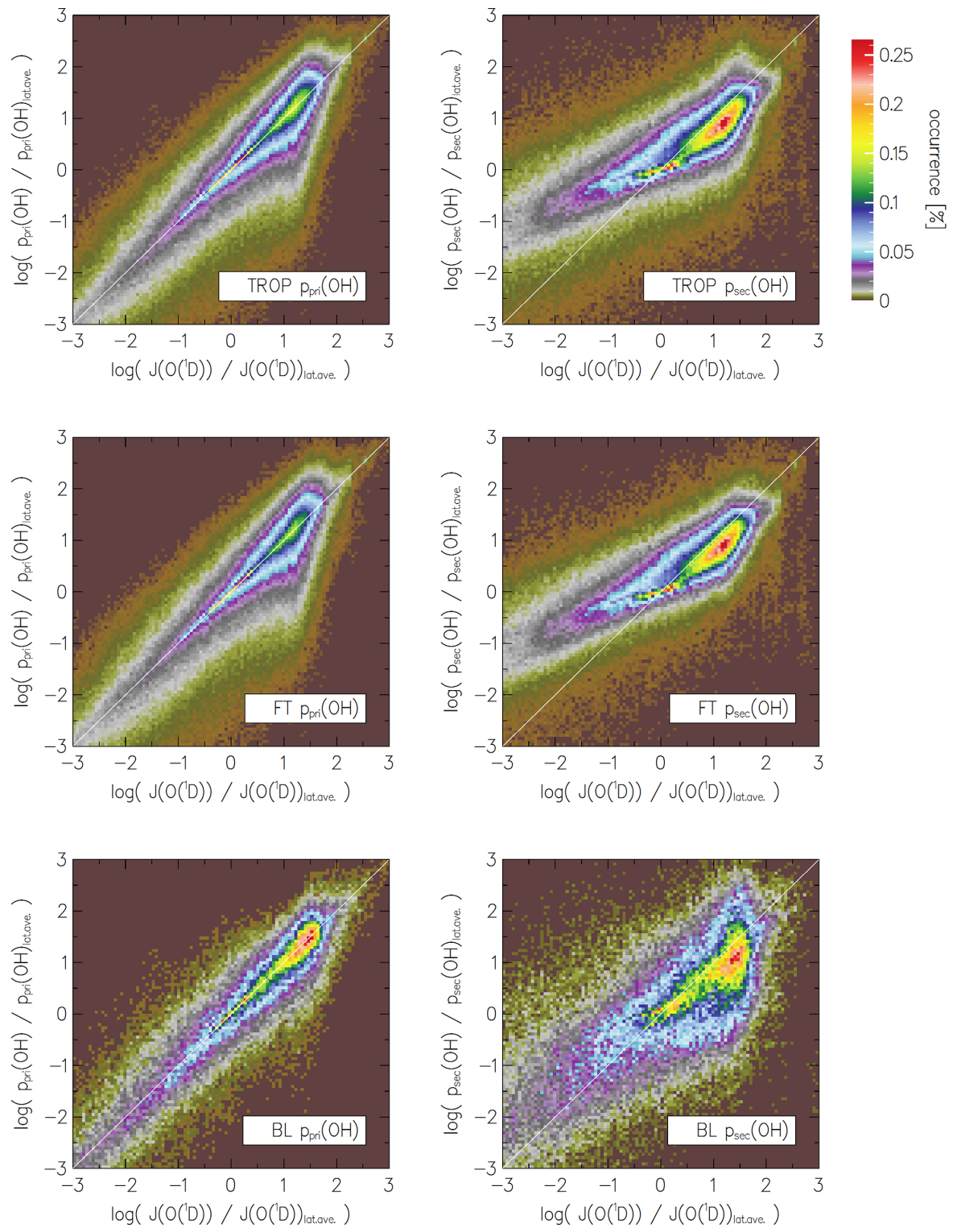

Figure 8. Correlation diagrams, showing $P$ and $S$ on the $y$ axes as a function of the photodissociation rate of $\mathrm{O}_{3}$ by $\mathrm{Reaction}(\mathrm{R} 1), J\left(\mathrm{O}^{1} \mathrm{D}\right)$, on the $x$ axes. Please notice the $\log -\log$ scale. $P$ is shown in the left panels and $S$ in the right panels, in the troposphere (top), FT (middle) and BL (bottom).

in the BL. Whereas in summer the $\mathrm{O}_{x}$ mechanism is most efficient, and to a lesser degree also the $\mathrm{NO}_{x}$ mechanism, in winter the OVOC mechanism maintains $\mathrm{OH}$ formation, being least dependent on solar radiation.

To estimate the contributions of the three recycling mechanisms $\left(\mathrm{NO}_{x}, \mathrm{O}_{x}, \mathrm{OVOC}\right)$ to global $\mathrm{OH}$ and $r$, we performed sensitivity simulations, switching them off one by one. By excluding $\mathrm{OH}$ recycling by $\mathrm{NO}_{x}$, the global mean $\mathrm{OH}$ concentration declines from $11.3 \times 10^{5}$ to $2.7 \times 10^{5}$ molecules $\mathrm{cm}^{-3}$, i.e., a reduction by $76 \%$, while $\tau_{\mathrm{CH}_{4}}$ increases from 8.5 to 21.6 years, $r$ reduces from 67 to $42 \%$ and the global mean production of $\mathrm{OH}$ drops from
4.8 to $2.8 \mathrm{ppbv} \mathrm{day}^{-1}$. This result corroborates the great importance of this mechanism and the sensitivity of global $\mathrm{OH}$ to $\mathrm{NO}_{x}$ abundance. The latter is illustrated by Fig. 11, which shows zonal mean $\mathrm{OH}$ concentrations by the reference simulation and by excluding the three $\mathrm{OH}$ recycling mechanisms one by one. The $\mathrm{NO}_{x}$ mechanism clearly has the largest impact on global $\mathrm{OH}$, i.e., through the partitioning between $\mathrm{OH}$ and $\mathrm{HO}_{2}$ and through the formation of $\mathrm{O}_{3}$. Figure 11 also shows that model-calculated $\mathrm{OH}$ exhibits nearinterhemispheric parity in the FT, while the $\mathrm{NO}_{x}$ mechanism leads to more $\mathrm{OH}$ in the $\mathrm{NH}$, primarily in the subtropical boundary layer. 


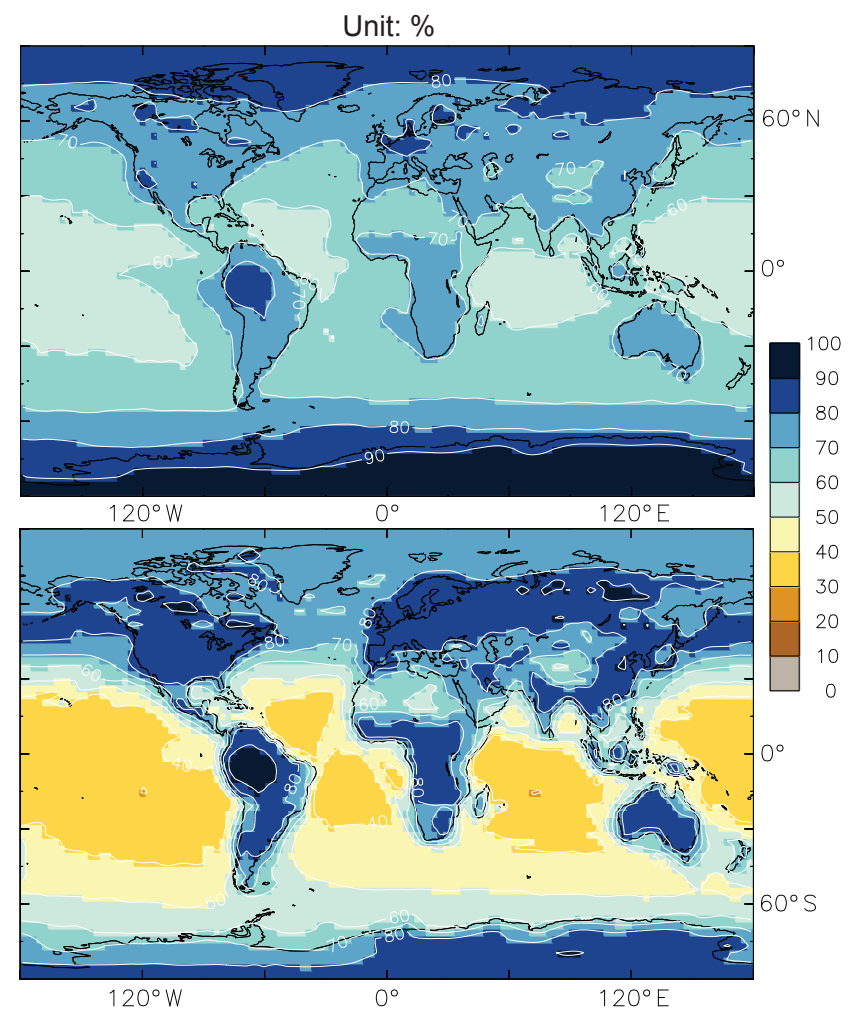

Figure 9. Annual mean $\mathrm{OH}$ recycling probability $(r$ in $\%)$ in the troposphere (top) and the BL (bottom).

The strength of the $\mathrm{O}_{x}$ mechanism comes second in magnitude, as its omission leads to a drop in global $\mathrm{OH}$ from $11.3 \times 10^{5}$ to $5.9 \times 10^{5}$ molecules $\mathrm{cm}^{-3}$, i.e., a reduction by $48 \%$, while $\tau_{\mathrm{CH}_{4}}$ increases from 8.5 to 15.0 years, $r$ reduces from 67 to $52 \%$ and the global mean production of $\mathrm{OH}$ de-

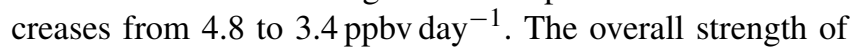
the OVOC mechanism is the weakest of the three. When we switch it off, global $\mathrm{OH}$ decreases from $11.3 \times 10^{5}$ to $9.7 \times 10^{5}$ molecules $\mathrm{cm}^{-3}$, i.e., a reduction by $14 \%$, while $\tau_{\mathrm{CH}_{4}}$ increases from 8.5 to 9.7 years, $r$ reduces from 67 to $61 \%$ and the global mean production of $\mathrm{OH}$ decreases from 4.8 to 4.2 ppbv day $^{-1}$. Note that in the latter sensitivity simulation we include $\mathrm{OH}$ recycling from $\mathrm{HO}_{2}$ that is produced through OVOC chemistry, which would otherwise contribute to the $\mathrm{NO}_{x}$ and $\mathrm{O}_{x}$ mechanisms. The $\mathrm{OH}$ formation through $\mathrm{HO}_{2}$, produced in the breakdown of VOC, accounts for about half the $\mathrm{OH}$ recycling by the $\mathrm{OVOC}$ mechanism.

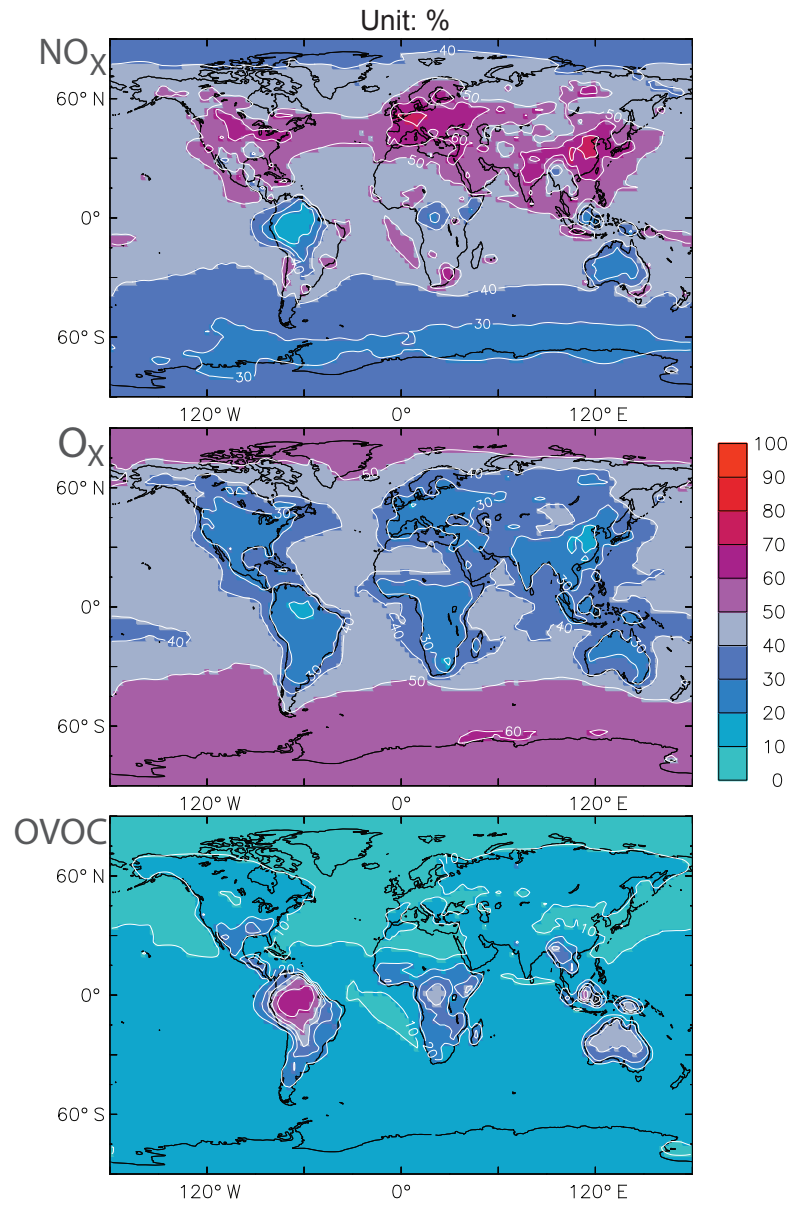

Figure 10. Fractional contributions to the $\mathrm{OH}$ recycling probability ( $\%$ of $r$ ) in the troposphere by the $\mathrm{NO}_{x}$ (top), $\mathrm{O}_{x}$ (middle) and OVOC (bottom) mechanisms (the sum of all three panels is $100 \%$ ).

\section{Conclusions}

The atmospheric oxidation capacity is generally not sensitive to perturbations that may arise from variations or trends in emissions of natural and anthropogenic origin. This is illustrated by global $\mathrm{OH}$ calculations with a large number of chemistry-transport models (Naik et al., 2013; Voulgarakis et al., 2013), where differences between models are larger than between preindustrial, present and future emission scenarios calculated by the same models. This suggests that model physics and chemistry formulations have a greater impact on calculations of global $\mathrm{OH}$ than applying different emission scenarios of source and sink gases. Results from the EMAC general circulation model illustrate how a combination of tropospheric chemistry and transport mechanisms buffer $\mathrm{OH}$ on a range of scales.

The EMAC model includes the recent Mainz Organics Mechanism to comprehensively account for VOC chemistry, including higher-generation reaction products, leading to a closed atmospheric budget of reactive carbon. The more real- 


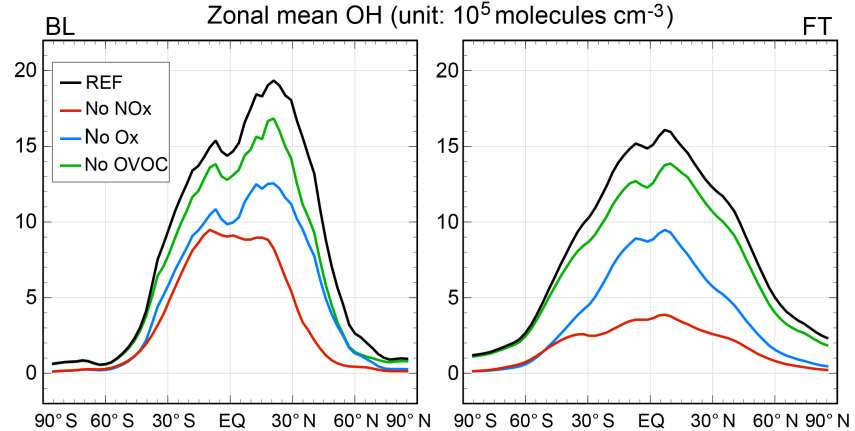

Figure 11. Zonal annual mean $\mathrm{OH}$ concentrations calculated in the reference simulation (black) and by successively excluding $\mathrm{OH}$ recycling through the $\mathrm{NO}_{x}, \mathrm{O}_{x}$ and OVOC mechanisms.

istic description of emissions and complex VOC chemistry in MOM compared to previous models substantially increases $\mathrm{OH}$ reactivity, bringing it close to measurements (Nölscher et al., 2016). We also find that in the polluted CBL, notably in the subtropical NH during summer, nighttime VOC chemistry, initiated by reaction with $\mathrm{O}_{3}$, can produce $\mathrm{OH}$ concentrations in excess of $10^{5}$ molecules $\mathrm{cm}^{-3}$, which may be relevant for particle nucleation, for example. Nevertheless, nighttime $\mathrm{OH}$ does not contribute significantly to the global atmospheric oxidation capacity (e.g., $\tau_{\mathrm{CH}_{4}}$ and $\tau_{\mathrm{CO}}$ ).

Global mean $\mathrm{OH}$ concentrations in the $\mathrm{BL}$ equal those in the FT and thus the troposphere as a whole $\left(11.3 \times 10^{5}\right.$ molecules $\left.\mathrm{cm}^{-3}\right)$. Tropospheric column average $\mathrm{OH}$ concentrations are highest in the tropics, especially over the Amazon, central Africa and southeastern Asia. Concentrations of $\mathrm{HO}_{x}\left(\mathrm{OH}+\mathrm{HO}_{2}\right)$ are highest in the $\mathrm{CBL}$ over the Amazon, central Africa and southeastern Asia, and some smaller regions over northern Australia, the USA north of the Mexican Gulf and near the Persian Gulf. The latter is related to emissions from the petroleum industry in photochemically polluted air.

While measurement campaigns often focus on the BL, the global distribution and variability of $\mathrm{OH}$ and $\mathrm{HO}_{x}$ are dominated by the FT. Long-distance transport processes and $\mathrm{OH}$ recycling are most efficient in the FT, whereas BL chemistry is more sensitive to local impacts of reactive carbon emissions. Chemical processes during transport in the FT play an important role in global $\mathrm{OH}$ buffering through oxidant transport, notably of ozone. The FT connects with the BL through convective mixing by clouds (latent heating) and entrainment by the diurnal evolution of the BL (sensible heating). The latter is more effective in the continental than in the marine environment.

While $\mathrm{HO}_{x}$ concentrations can diverge strongly over the globe, especially in the BL and between seasons, annual averages in the troposphere vary little, e.g., between the tropics and extratropics and between hemispheres. Tropospheric $\mathrm{OH}$ is buffered through complementary primary and secondary formation mechanisms throughout seasons, latitudes and altitudes. Globally, secondary $\mathrm{OH}$ formation exceeds primary formation - through Reactions (R1) and (R2) - by about a factor of 2, leading to an $\mathrm{OH}$ recycling probability of $67 \%$; hence global $\mathrm{OH}$ is not sensitive to perturbations by natural or anthropogenic emission changes. We find that primary $\mathrm{OH}$ formation is tightly related to solar UV radiation intensity, whereas this is much less the case for secondary $\mathrm{OH}$ formation. There are three principal pathways of secondary $\mathrm{OH}$ formation: the $\mathrm{NO}_{x}, \mathrm{O}_{x}$ and OVOC mechanisms.

The $\mathrm{NO}_{x}$ mechanism predominates in anthropogenically influenced environments, causing photochemical smog with high ozone concentrations, and outcompetes the OVOC mechanism concomitant with VOC emissions from vegetation. The $\mathrm{NO}_{x}$ mechanism contributes greatly to global $\mathrm{OH}$ and $\mathrm{O}_{3}$. When we switch it off in the model, global $\mathrm{OH}$ declines by $76 \%$ and $\tau_{\mathrm{CH}_{4}}$ increases by a factor of 2.5 . In regions where $\mathrm{NO}_{x}$ is low the photochemistry of natural VOCs, through the breakdown of OVOC and their reaction products, can govern radical recycling and maintain the atmospheric oxidation capacity associated with undisturbed atmospherebiosphere interactions. While the OVOC mechanism is important for $\mathrm{OH}$ production over forests, excluding it reduces global $\mathrm{OH}$ by $14 \%$. In regions where both $\mathrm{NO}_{x}$ and VOC concentrations are low, e.g., in the remote marine environment and at high latitudes, $\mathrm{OH}$ recycling strongly depends on the $\mathrm{O}_{x}$ mechanism. When we switch it off, global mean OH drops by $48 \%$.

Recycling mechanisms of $\mathrm{OH}$ are important near emission sources of $\mathrm{NO}_{x}$ and VOCs in regions of active photochemistry in the BL, but especially in remote areas and the FT where photochemistry is less active. On large scales ozone is a key buffer of $\mathrm{OH}$. To a lesser degree $\mathrm{NO}_{x}$ reservoir species (e.g., organic nitrates) also play a role. On smaller scales, $\mathrm{H}_{2} \mathrm{O}_{2}$ and OVOCs that release $\mathrm{OH}$ upon further reaction and photodissociation (e.g., organic peroxides and carbonyls) are important. These short-lived reservoir species govern $\mathrm{OH}$ sources and sinks within the column. Ozone, with a lifetime of several weeks in the FT, is central to the atmospheric oxidation capacity through long-distance transport, either from the stratosphere or from photochemically polluted regions, through primary $\mathrm{OH}$ formation and $\mathrm{OH}$ recycling in natural and anthropogenically influenced atmospheres.

\section{Data availability}

Model-calculated global datasets of $\mathrm{OH}$ concentrations, other trace gases, and controlling parameters are available upon request. The full VOC oxidation mechanism is given in the Supplement.

The Supplement related to this article is available online at doi:10.5194/acp-16-12477-2016-supplement. 
The article processing charges for this open-access publication were covered by the Max Planck Society.

Edited by: M. Kanakidou

Reviewed by: four anonymous referees

\section{References}

Arneth, A., Harrison, S. P., Zaehle, S., Tsigaridis, K., Menon, S., Bartlein, P. J., Feichter, J., Korhola, A., Kulmala, M., O’Donnell, D., Schurgers, G., Sorvari, S., and Vesala, T.: Terrestrial biogeochemical feedbacks in the climate system, Nat. Geosci., 3, 525532, 2010.

Butler, T. M., Lawrence, M. G., Taraborrelli, D., and Lelieveld, J.: Tagged ozone production potential (TOPP) of volatile organic compounds, Atmos. Environ., 45, 4082-4090, 2011.

Cabrera-Perez, D., Taraborrelli, D., Sander, R., and Pozzer, A.: Global atmospheric budget of simple monocyclic aromatic compounds, Atmos. Chem. Phys., 16, 6931-6947, doi:10.5194/acp16-6931-2016, 2016.

Christoudias, T. and Lelieveld, J.: Modelling the global atmospheric transport and deposition of radionuclides from the Fukushima Dai-ichi nuclear accident, Atmos. Chem. Phys., 13, 1425-1438, doi:10.5194/acp-13-1425-2013, 2013.

Crounse, J. D., Knap, H. C., Ørnsø, K. B., Jørgensen, S., Paulot, F., Kjaergaard, G. G., and Wennberg, P. O.: Atmospheric fate of methacrolein. 1. Peroxy radical isomerization following addition of $\mathrm{OH}$ and $\mathrm{O}_{2}$, J. Phys. Chem. A, 116, 5756-5762, 2012.

Crounse, J. D., Nielsen, L. B., Jørgensen, S., Kjaergaard, H. G., and Wennberg, P. O.: Autoxidation of organic compounds in the atmosphere, J. Phys. Chem. Lett., 4, 3513-3520, 2013.

Crutzen, P. J.: A discussion of the chemistry of some minor constituents in the stratosphere and troposphere, Pure App. Geophys., 106-108, 1385-1399, 1973.

Crutzen, P. J. and Zimmermann, P. H.: The changing photochemistry of the troposphere, Tellus, 43AB, 136-151, 1991.

Deckert, R., Jöckel, P., Grewe, V., Gottschaldt, K.-D., and Hoor, P.: A quasi chemistry-transport model mode for EMAC, Geosci. Model Dev., 4, 195-206, doi:10.5194/gmd-4-195-2011, 2011.

De Laat, A. T. J. and Lelieveld, J.: Diurnal ozone cycle in the marine boundary layer, J. Geophys. Res., 105, 11547-11559, 2000.

De Meij, A., Pozzer, A., Pringle, K. J., Tost, H., and Lelieveld, J.: EMAC model evaluation and analysis of atmospheric aerosol properties and distribution, Atmos. Res., 114-115, 38-69, 2012.

Ehhalt, D. H., Dorn, H.-P., and Poppe, D.: The chemistry of the hydroxyl radical in the troposphere, Proc. R. Soc. Edinb. B., 97, 17-34, 1991.

Elshorbany, Y. F., Crutzen, P. J., Steil, B., Pozzer, A., Tost, H., and Lelieveld, J.: Global and regional impacts of HONO on the chemical composition of clouds and aerosols, Atmos. Chem. Phys., 14, 1167-1184, doi:10.5194/acp-14-1167-2014, 2014.

Fuchs, H., Acir, I.-H., Bohn, B., Brauers, T., Dorn, H.-P., Häseler, R., Hofzumahaus, A., Holland, F., Kaminski, M., Li, X., Lu, K., Lutz, A., Nehr, S., Rohrer, F., Tillmann, R., Wegener, R., and Wahner, A.: $\mathrm{OH}$ regeneration from methacrolein oxidation investigated in the atmosphere simulation chamber SAPHIR, At- mos. Chem. Phys., 14, 7895-7908, doi:10.5194/acp-14-78952014, 2014.

Granier, C., Bessagnet, B., Bond, T., D’Angiola, A., van der Gon, H. D., Frost, G. J., Heil, A., Kaiser, J. W., Kinne, S., Klimont, Z., Kloster, S., Lamarque, J.-F., Liousse, C., Masui, T., Meleux, F., Mieville, A., Ohara, T., Raut, J.-C., Riahi, K., Schultz, M. G., Smith, S. J., Thompson, A., van Aardenne, J., van der Werf, G. R., and van Vuuren, D. P.: Evolution of anthropogenic and biomass burning emissions of air pollutants at global and regional scales during the 1980-2010 period, Climatic Change, 109, 163-190, 2011.

Groß, C. B. M., Dillon, T. J., Schuster, G., Lelieveld, J., and Crowley, J. N.: Direct kinetic study of $\mathrm{OH}$ and $\mathrm{O}_{3}$ formation in the reaction of $\mathrm{CH}_{3} \mathrm{C}(\mathrm{O}) \mathrm{O}_{2}$ with $\mathrm{HO}_{2}$, J. Phys. Chem. A, 118, 974 985, 2014a.

Groß, C. B. M., Dillon, T. J., and Crowley, J. N.: Pressure dependent $\mathrm{OH}$ yields in the reactions of $\mathrm{CH}_{3} \mathrm{CO}$ and $\mathrm{HOCH}_{2} \mathrm{CO}$ with $\mathrm{O}_{2}$, Phys. Chem. Chem. Phys., 16, 10990-10998, 2014b.

Gromov, S., Jöckel, P., Sander, R., and Brenninkmeijer, C. A. M.: A kinetic chemistry tagging technique and its application to modelling the stable isotopic composition of atmospheric trace gases, Geosci. Model Dev., 3, 337-364, doi:10.5194/gmd-3-337-2010, 2010.

Guenther, A. B., Jiang, X., Heald, C. L., Sakulyanontvittaya, T., Duhl, T., Emmons, L. K., and Wang, X.: The Model of Emissions of Gases and Aerosols from Nature version 2.1 (MEGAN2.1): an extended and updated framework for modeling biogenic emissions, Geosci. Model Dev., 5, 1471-1492, doi:10.5194/gmd-51471-2012, 2012.

Houweling, S., Dentener, F., and Lelieveld, J.: The impact of nonmethane hydrocarbon compounds on tropospheric photochemistry, J. Geophys. Res., 103, 10673-10696, 1998.

Jenkin, M. E., Young, J. C., and Rickard, A. R.: The MCM v3.3.1 degradation scheme for isoprene, Atmos. Chem. Phys., 15, 11433-11459, doi:10.5194/acp-15-11433-2015, 2015.

Jöckel, P., Sander, R., Kerkweg, A., Tost, H., and Lelieveld, J.: Technical Note: The Modular Earth Submodel System (MESSy) - a new approach towards Earth System Modeling, Atmos. Chem. Phys., 5, 433-444, doi:10.5194/acp-5-433-2005, 2005.

Jöckel, P., Tost, H., Pozzer, A., Brühl, C., Buchholz, J., Ganzeveld, L., Hoor, P., Kerkweg, A., Lawrence, M. G., Sander, R., Steil, B., Stiller, G., Tanarhte, M., Taraborrelli, D., van Aardenne, J., and Lelieveld, J.: The atmospheric chemistry general circulation model ECHAM5/MESSy1: consistent simulation of ozone from the surface to the mesosphere, Atmos. Chem. Phys., 6, 50675104, doi:10.5194/acp-6-5067-2006, 2006.

Jöckel, P., Kerkweg, A., Pozzer, A., Sander, R., Tost, H., Riede, H., Baumgaertner, A., Gromov, S., and Kern, B.: Development cycle 2 of the Modular Earth Submodel System (MESSy2), Geosci. Model Dev., 3, 717-752, doi:10.5194/gmd-3-717-2010, 2010.

Kerkweg, A., Sander, R., Tost, H., and Jöckel, P.: Technical note: Implementation of prescribed (OFFLEM), calculated (ONLEM), and pseudo-emissions (TNUDGE) of chemical species in the Modular Earth Submodel System (MESSy), Atmos. Chem. Phys., 6, 3603-3609, doi:10.5194/acp-6-3603-2006, 2006.

Krol, M. and Lelieveld, J.: Can the variability in tropospheric $\mathrm{OH}$ be deduced from measurements of 1,1,1-trichloroethane (methyl chloroform)?, J. Geophys. Res., 108, 4125, doi:10.1029/2002JD002423, 2003. 
Kubistin, D., Harder, H., Martinez, M., Rudolf, M., Sander, R., Bozem, H., Eerdekens, G., Fischer, H., Gurk, C., Klüpfel, T., Königstedt, R., Parchatka, U., Schiller, C. L., Stickler, A., Taraborrelli, D., Williams, J., and Lelieveld, J.: Hydroxyl radicals in the tropical troposphere over the Suriname rainforest: comparison of measurements with the box model MECCA, Atmos. Chem. Phys., 10, 9705-9728, doi:10.5194/acp-10-97052010, 2010.

Lawrence, M. G., Jöckel, P., and von Kuhlmann, R.: What does the global mean $\mathrm{OH}$ concentration tell us?, Atmos. Chem. Phys., 1, 37-49, doi:10.5194/acp-1-37-2001, 2001.

Lelieveld, J. and Dentener, F. J.: What controls tropospheric ozone?, J. Geophys. Res., 105, 3531-3551, 2000.

Lelieveld, J., Peters, W., Dentener, F. J., and Krol: M. Stability of tropospheric hydroxyl chemistry, J. Geophys. Res., 107, 4715, doi:10.1029/2002JD002272, 2002.

Lelieveld, J., Brühl, C., Jöckel, P., Steil, B., Crutzen, P. J., Fischer, H., Giorgetta, M. A., Hoor, P., Lawrence, M. G., Sausen, R., and Tost, H.: Stratospheric dryness: model simulations and satellite observations, Atmos. Chem. Phys., 7, 1313-1332, doi:10.5194/acp-7-1313-2007, 2007.

Lelieveld, J., Butler, T. M., Crowley, J. N., Dillon, T. J., Fischer, H., Ganzeveld, L., Harder, H., Lawrence, M. G., Martinez, M., Taraborrelli, D., and Williams, J.: Atmospheric oxidation capacity sustained by a forest, Nature, 452, 737-740, 2008.

Lelieveld, J., Hoor, P., Jöckel, P., Pozzer, A., Hadjinicolaou, P., Cammas, J.-P., and Beirle, S.: Severe ozone air pollution in the Persian Gulf region, Atmos. Chem. Phys., 9, 1393-1406, doi:10.5194/acp-9-1393-2009, 2009.

Levy II, H.: Normal atmosphere: large radical and formaldehyde concentrations predicted, Science, 173, 141-143, 1971.

Logan, J. A., Prather, M. J., Wofsy, S. C., and McElroy, M. B.: Tropospheric chemistry: A global perspective, J. Geophys. Res., 86, 7210-7354, 1981.

Meinshausen, M., Smith, S. J., Calvin, K., Daniel, J. S., Kainuma, M. L. T., Lamarque, J.-F., Matsumoto, K., Montzka, S. A., Raper, S. C. B., Riahi, K., Thomson, A., Velders, G. J. M., and van Vuuren, D. P. P.: The RCP greenhouse gas concentrations and their extensions from 1765 to 2300, Climatic Change, 109, 213-241, 2011.

Mogensen, D., Gierens, R., Crowley, J. N., Keronen, P., Smolander, S., Sogachev, A., Nölscher, A. C., Zhou, L., Kulmala, M., Tang, M. J., Williams, J., and Boy, M.: Simulations of atmospheric $\mathrm{OH}, \mathrm{O}_{3}$ and $\mathrm{NO}_{3}$ reactivities within and above the boreal forest, Atmos. Chem. Phys., 15, 3909-3932, doi:10.5194/acp-15-39092015, 2015.

Monks, P. S., Archibald, A. T., Colette, A., Cooper, O., Coyle, M., Derwent, R., Fowler, D., Granier, C., Law, K. S., Mills, G. E., Stevenson, D. S., Tarasova, O., Thouret, V., von Schneidemesser, E., Sommariva, R., Wild, O., and Williams, M. L.: Tropospheric ozone and its precursors from the urban to the global scale from air quality to short-lived climate forcer, Atmos. Chem. Phys., 15, 8889-8973, doi:10.5194/acp-15-8889-2015, 2015.

Montzka, S., Krol, M., Dlugokencky, E., Hall, B., Jöckel, P., and Lelieveld, J.: Small inter-annual variability of global atmospheric hydroxyl, Science, 331, 67-69, 2011.
Naik, V., Voulgarakis, A., Fiore, A. M., Horowitz, L. W., Lamarque, J.-F., Lin, M., Prather, M. J., Young, P. J., Bergmann, D., Cameron-Smith, P. J., Cionni, I., Collins, W. J., Dalsøren, S. B., Doherty, R., Eyring, V., Faluvegi, G., Folberth, G. A., Josse, B., Lee, Y. H., MacKenzie, I. A., Nagashima, T., van Noije, T. P. C., Plummer, D. A., Righi, M., Rumbold, S. T., Skeie, R., Shindell, D. T., Stevenson, D. S., Strode, S., Sudo, K., Szopa, S., and Zeng, G.: Preindustrial to present-day changes in tropospheric hydroxyl radical and methane lifetime from the Atmospheric Chemistry and Climate Model Intercomparison Project (ACCMIP), Atmos. Chem. Phys., 13, 5277-5298, doi:10.5194/acp-13-5277-2013, 2013.

Nölscher, A. C., Butler, T., Auld, J., Veres, P., Muñoz, A., Taraborrelli, D., Vereecken, L., Lelieveld, J., and Williams, J.: Using total $\mathrm{OH}$ reactivity to assess isoprene photooxidation via measurement and model, Atmos. Environ., 89, 453-463, 2014.

Nölscher, A. C., Yanez-Serrano, A. M., Wolff, S., Carioca de Araujo, A., Lavric, J. V., Kesselmeier, J., and Williams, J.: Unexpected seasonality in quantity and composition of Amazon rainforest air reactivity, Nature Communications, 7, 10383 doi:10.1038/ncomms10383, 2016.

Patra P. K., Krol, M. C., Montzka, S. A., Arnold, T., Atlas, E. L., Lintner, B. R., Stephens, B. B., Xiang, B., Elkins, J. W., Fraser, P. J., Ghosh, A., Hintsa, E. J., Hurst, D. F., Ishijima, K., Krummel, P. B., Miller, B. R., Miyazaki, K., Moore, F. L., Mühle, J., O’Doherty, S., Prinn, R. G., Steele, L. P., Takigawa, M., Wang, H. J., Weiss, R. F., Wofsy, S. C., and Young, D.: Observational evidence for interhemispheric hydroxyl-radical parity, Nature, 513, 219-223, 2014.

Paulot, F., Crounse, J. D., Kjaergaard, H. G., Kürten, A., St. Clair, J. M., Seinfeld, J. H., and Wennberg, P. O.: Unexpected epoxide formation in the gas-phase photooxidation of isoprene, Science, 325, 730-733, 2009.

Peeters, J., Müller, J.-F., Stavrakou, T., and Nguyen, V. S.: Hydroxyl radical Recycling in isoprene oxidation driven by hydrogen bonding and hydrogen tunneling: The upgraded LIM1 mechanism, J. Phys. Chem., A, 118, 8625-8643, 2014.

Pozzer, A., Jöckel, P., Tost, H., Sander, R., Ganzeveld, L., Kerkweg, A., and Lelieveld, J.: Simulating organic species with the global atmospheric chemistry general circulation model ECHAM5/MESSy1: a comparison of model results with observations, Atmos. Chem. Phys., 7, 2527-2550, doi:10.5194/acp-72527-2007, 2007.

Pozzer, A., Pollmann, J., Taraborrelli, D., Jöckel, P., Helmig, D., Tans, P., Hueber, J., and Lelieveld, J.: Observed and simulated global distribution and budget of atmospheric $\mathrm{C}_{2}-\mathrm{C}_{5}$ alkanes, Atmos. Chem. Phys., 10, 4403-4422, doi:10.5194/acp-10-44032010, 2010.

Pozzer, A., Jöckel, P., Kern, B., and Haak, H.: The AtmosphereOcean General Circulation Model EMAC-MPIOM, Geosci. Model Dev., 4, 771-784, doi:10.5194/gmd-4-771-2011, 2011.

Pozzer, A., de Meij, A., Pringle, K. J., Tost, H., Doering, U. M., van Aardenne, J., and Lelieveld, J.: Distributions and regional budgets of aerosols and their precursors simulated with the EMAC chemistry-climate model, Atmos. Chem. Phys., 12, 961-987, doi:10.5194/acp-12-961-2012, 2012.

Pringle, K. J., Tost, H., Message, S., Steil, B., Giannadaki, D., Nenes, A., Fountoukis, C., Stier, P., Vignati, E., and Lelieveld, J.: Description and evaluation of GMXe: a new aerosol submodel 
for global simulations (v1), Geosci. Model Dev., 3, 391-412, doi:10.5194/gmd-3-391-2010, 2010.

Pugh, T. A. M., MacKenzie, A. R., Hewitt, C. N., Langford, B., Edwards, P. M., Furneaux, K. L., Heard, D. E., Hopkins, J. R., Jones, C. E., Karunaharan, A., Lee, J., Mills, G., Misztal, P., Moller, S., Monks, P. S., and Whalley, L. K.: Simulating atmospheric composition over a South-East Asian tropical rainforest: performance of a chemistry box model, Atmos. Chem. Phys., 10, 279-298, doi:10.5194/acp-10-279-2010, 2010.

Ren, X., van Duin, D., Cazorla, M., Chen, S., Mao, J., Zhang, L., Brune, W. H., Flynn, J. H., Grossberg, N., Lefer, B. L., Rappenglück, B., Wong, K. W., Tsai, C., Stutz, J., Dibb, J. E., Jobson, T., Luke, W. T., and Kelley, P.: Atmospheric oxidation chemistry and ozone production: Results from SHARP 2009 in Houston, Texas, J. Geophys. Res., 118, 5770-5780, 2013.

Riahi, K., Gruebler, A., and Nakicenovic, N.: Scenarios of longterm socio-economic and environmental development under climate stabilization, Technol. Forecast. Soc., 74, 887-935, 2007.

Roeckner, E., Brokopf, R., Esch, M., Giorgetta, M., Hagemann, S., Kornblüh, Manzini, L. E., Schlese, U., and Schulzweida, U.: Sensitivity of simulated climate to horizontal and vertical resolution in the ECHAM5 atmosphere model, J. Climate, 19, 3771-3791, 2006.

Rohrer, F. and Berresheim, H.: Strong correlation between levels of tropospheric hydroxyl radicals and solar ultraviolet radiation, Nature, 442, 184-187, 2006.

Rohrer, F., Lu, K., Hofzumahaus, A., Bohn, B., Brauers, T., Chang, C.-C., Fuchs, H., Häseler, R., Holland, F., Hu, M., Kita, K., Kondo, Y., Li, X., Lou, S., Oebel, A., Shao, M., Zeng, L., Zhu, T., Zhang, Y., and Wahner, A.: Maximum efficiency in the hydroxylradical-based self-cleansing of the troposphere, Nat. Geosci., 7, 559-563, 2014.

Sander, R., Kerkweg, A., Jöckel, P., and Lelieveld, J.: Technical note: The new comprehensive atmospheric chemistry module MECCA, Atmos. Chem. Phys., 5, 445-450, doi:10.5194/acp-5445-2005, 2005.

Sander, R., Baumgaertner, A., Gromov, S., Harder, H., Jöckel, P., Kerkweg, A., Kubistin, D., Regelin, E., Riede, H., Sandu, A., Taraborrelli, D., Tost, H., and Xie, Z.-Q.: The atmospheric chemistry box model CAABA/MECCA-3.0, Geosci. Model Dev., 4, 373-380, doi:10.5194/gmd-4-373-2011, 2011.

Sander, R., Jöckel, P., Kirner, O., Kunert, A. T., Landgraf, J., and Pozzer, A.: The photolysis module JVAL-14, compatible with the MESSy standard, and the JVal PreProcessor (JVPP), Geosci. Model Dev., 7, 2653-2662, doi:10.5194/gmd-7-26532014, 2014.

Schneider, P. and van der A, R. J.: A global single-sensor analysis of 2002-2011 tropospheric nitrogen dioxide trends observed from space, J. Geophys. Res., 117, D16309, doi:10.1029/2012JD017571, 2012.

Spivakovsky, C. M., Logan, J. A., Montzka, S. A., Balkanski, Y. J., Foreman-Fowler, M., Jones, D. B. A., Horowitz, L. A., Fusco, A. C., Brenninkmeijer, C. A. M., Prather, M. J., Wofsy, S. C., and McElroy, M. B.: Three-dimensional climatological distribution of tropospheric OH: Update and evaluation, J. Geophys. Res., 105, 8931-8980, 2000.
Stockwell, W. R., Lawson, C. V., Saunders, E., and Goliff, W. S.: A review of tropospheric atmospheric chemistry and gas-phase chemical mechanisms for air quality modeling, Atmosphere, 3, $1-32,2012$.

Stone, D., Whalley, L. K., and Heard, D. E.: Tropospheric OH and $\mathrm{HO}_{2}$ radicals: field measurements and model comparisons, Chem. Soc. Rev., 41, 6348-6404, 2012.

Taraborrelli, D., Lawrence, M. G., Butler, T. M., Sander, R., and Lelieveld, J.: Mainz Isoprene Mechanism 2 (MIM2): an isoprene oxidation mechanism for regional and global atmospheric modelling, Atmos. Chem. Phys., 9, 2751-2777, doi:10.5194/acp-92751-2009, 2009.

Taraborrelli, D., Lawrence, M. G., Crowley, J. N., Dillon, T. J., Gromov, S., Groß, C. B. M., Vereecken, L., and Lelieveld, J.: Hydroxyl radical buffered by isoprene oxidation over tropical forests, Nat. Geosci., 5, 190-193, 2012.

Tost, H., Jöckel, P., Kerkweg, A., Sander, R., and Lelieveld, J.: Technical note: A new comprehensive SCAVenging submodel for global atmospheric chemistry modelling, Atmos. Chem. Phys., 6, 565-574, doi:10.5194/acp-6-565-2006, 2006.

Tost, H., Jöckel, P., Kerkweg, A., Pozzer, A., Sander, R., and Lelieveld, J.: Global cloud and precipitation chemistry and wet deposition: tropospheric model simulations with ECHAM5/MESSy1, Atmos. Chem. Phys., 7, 2733-2757, doi:10.5194/acp-7-2733-2007, 2007a.

Tost, H., Jöckel, P., and Lelieveld, J.: Lightning and convection parameterisations - uncertainties in global modelling, Atmos. Chem. Phys., 7, 4553-4568, doi:10.5194/acp-7-4553-2007, 2007b.

Tsimpidi, A. P., Karydis, V. A., Pandis, S. N., and Lelieveld, J.: Global combustion sources of organic aerosols: model comparison with 84 AMS factor-analysis data sets, Atmos. Chem. Phys., 16, 8939-8962, doi:10.5194/acp-16-8939-2016, 2016.

van Vuuren, D. P., Edmonds, J. A., Kainuma, M., Riahi, K., Thomson, A. M., Hibbard, K., Hurtt, G. C., Kram, T., Krey, V., Lamarque, J.-F., Masui, T., Nakicenovic, M. M. N., Smith, S. J., and Rose, S.: The representative concentration pathways: an overview, Climatic Change, 109, 5-31, 2011.

Vereecken, L. and Francisco, J. S.: Theoretical studies of atmospheric reaction mechanisms in the troposphere, Chem. Soc. Rev., 41, 6259-6293, 2012.

Voulgarakis, A., Naik, V., Lamarque, J.-F., Shindell, D. T., Young, P. J., Prather, M. J., Wild, O., Field, R. D., Bergmann, D., CameronSmith, P., Cionni, I., Collins, W. J., Dalsøren, S. B., Doherty, R. M., Eyring, V., Faluvegi, G., Folberth, G. A., Horowitz, L. W., Josse, B., MacKenzie, I. A., Nagashima, T., Plummer, D. A., Righi, M., Rumbold, S. T., Stevenson, D. S., Strode, S. A., Sudo, K., Szopa, S., and Zeng, G.: Analysis of present day and future $\mathrm{OH}$ and methane lifetime in the ACCMIP simulations, Atmos. Chem. Phys., 13, 2563-2587, doi:10.5194/acp-13-25632013, 2013.

Whalley, L. K., Edwards, P. M., Furneaux, K. L., Goddard, A., Ingham, T., Evans, M. J., Stone, D., Hopkins, J. R., Jones, C. E., Karunaharan, A., Lee, J. D., Lewis, A. C., Monks, P. S., Moller, S. J., and Heard, D. E.: Quantifying the magnitude of a missing hydroxyl radical source in a tropical rainforest, Atmos. Chem. Phys., 11, 7223-7233, doi:10.5194/acp-11-7223-2011, 2011. 
Worden, H. M., Deeter, M. N., Frankenberg, C., George, M., Nichitiu, F., Worden, J., Aben, I., Bowman, K. W., Clerbaux, C., Coheur, P. F., de Laat, A. T. J., Detweiler, R., Drummond, J. R., Edwards, D. P., Gille, J. C., Hurtmans, D., Luo, M., MartínezAlonso, S., Massie, S., Pfister, G., and Warner, J. X.: Decadal record of satellite carbon monoxide observations, Atmos. Chem. Phys., 13, 837-850, doi:10.5194/acp-13-837-2013, 2013.
Yoon, J. and Pozzer, A.: Model-simulated trend of surface carbon monoxide for the 2001-2010 decade, Atmos. Chem. Phys., 14, 10465-10482, doi:10.5194/acp-14-10465-2014, 2014. 